\title{
Systematic Review of Systemic Therapies and Therapeutic Combinations with Local Treatments for High-risk Localized Prostate Cancer
}

\author{
Lorenzo Tosco, Alberto Briganti, Antony Vincent D'amico, James Eastham, \\ Mario Eisenberger, Martin Gleave, Karin Haustermans, Christopher J. Logothetis, \\ Fred Saad, Christopher Sweeney, Mary-Ellen Taplin, Karim Fizazi
}

\begin{abstract}
Context: Systemic therapies, combined with local treatment for high-risk prostate cancer, are recommended by the international guidelines for specific subgroups of patients; however, for many of the clinical scenarios, it remains a research field.
\end{abstract}

Objective: To perform a systematic review, and describe current evidence and perspectives about the multimodal treatment of high-risk prostate cancer.

Evidence acquisition: We performed a systematic review of PubMED, Embase, Cochrane Library, European Society of Medical Oncology/American Society of Clinical Oncology Annual proceedings, and clinicalTrial.gov between January 2010 and February 2018 following the Preferred Reporting Items for Systematic Reviews and Meta-analysis statement.

Evidence synthesis: Seventy-seven prospective trials were identified. According to multiple randomized trials, combining androgen deprivation therapy (ADT) with external-beam radiotherapy (EBRT) outperforms EBRT alone for both relapse-free and overall survival. Neoadjuvant ADT did not show significant improvement compared with prostatectomy alone. The role of adjuvant ADT after prostatectomy in patients with high-risk disease is still debated, with lack of data from phase 3 trials in pNO patients.

Novel androgen pathway inhibitors have been tested only in early-phase trials in addition to primary treatment. GETUG 12 , RTOG 0521, and nonmetastatic subgroup of the STAMPEDE trial showed improved relapse-free survival for docetaxel in patients treated with EBRT plus ADT, although mature metastasis-free survival data are still pending. Both the SPCG-12 and the VACSP\#553 trial showed no improvement in relapse free survival for adjuvant docetaxel after prostatectomy.

Conclusions: In contrast to the clearly demonstrated survival benefits of long-term adjuvant ADT when used with EBRT, its role after prostatectomy remains unclear especially in pNO patients. Adding docetaxel to EBRT-ADT improves relapse-free survival, with immature results on overall survival. Novel androgen receptor pathway inhibitors are currently being tested in the neoadjuvant and adjuvant setting.

Patient summary: Treatment of high-risk prostate cancer is based on a multimodality approach that includes systemic treatments. The best treatment or therapy combination remains to be defined. 


\section{Introduction}

Prostate cancer is the second leading cause of malignant tumors in men worldwide after lung cancer, and it still represents the fifth cause of cancer-specific mortality (CSM) [1]. The definition of high-risk prostate cancer is still heterogeneous, but it is most commonly defined as men having one or more of these features [2,3]: initial prostate specific antigen (iPSA) $>20$ $\mathrm{ng} / \mathrm{ml}$, biopsy Gleason score (bGS) $>7$, and clinical stage $\geq \mathrm{T} 2 \mathrm{c}$. High-risk prostate cancer is clearly the most concerning form of localized disease with $35.5 \%$ cumulative mortality at 15 yr [4]. The addition of androgen deprivation therapy (ADT) to external-beam radiotherapy (EBRT) improved overall survival (OS) compared with radiotherapy alone (hazard ratio [HR] $0.60,95 \%$ confidence interval [Cl] $0.45-0.80 ; p=0.0004)$ [5]. Surgery, in selected patients from nonrandomized studies, was associated with 10-yr CSM rates ranging from $3 \%$ to $11 \%$ depending on the definition used [6]. The rationale behind the combination of treatments is to eradicate as much as possible the primary tumor as well as the micrometastatic clones. The cytotoxic mechanisms of chemotherapy, for example, have a potential effect not only on differentiated cancer cells, but also on prostate cancer stem cells, which do not express androgen receptor [7]. ADT, conversely, is effective against androgen-sensitive cells, and it is able to radiosensitize prostate cancer cells to radiation therapy [8]. It was also suggested that the combination of ADT and chemotherapy has a synergic and more powerful effect compared with their sequential use [9]. A recent meta-analysis, including data from different studies (GETUG-AFU 15 [10], CHAARTED [11], and STAMPEDE [12]), confirmed the positive effect of adding docetaxel with an $\mathrm{HR}$ of 0.77 (95\% $\mathrm{Cl} 0.68-0.87)$ for $\mathrm{OS}$ and $0.64(95 \% \mathrm{Cl} 0.58-0.70)$ for failure-free survival in metastatic castration-naive patients. In nonmetastatic patients, the use of chemotherapy significantly improved failure-free survival ( $\mathrm{HR} 0.70 ; 95 \% \mathrm{Cl} 0.61-0.81$ ) and data were immature for OS analysis [13]. Next-generation ADT (abiraterone and enzalutamide) improves OS in castration-resistant prostate cancer (CRPC) [14], and trials are now testing these agents at early stages. This systematic review aims to assess the literature broadly in the era of second-generation androgen receptor pathway inhibitors, exploring and analyzing novel and future systemic therapies, or therapeutic combinations, in association with the most common primary treatments for high-risk prostate cancer.

\section{Evidence acquisition}

We performed a systematic review based on five different search sources between January 2010 and February 2018: PubMED (Supplementary material), Embase, Cochrane Library, ClinicalTrial.gov, European Society of Medical Oncology Congress proceedings in the Annals of Oncology, and American Society of Clinical Oncology (ASCO) annual meeting proceedings in ASCO Meeting Library. Medical Subject Headings and Emtree vocabularies were applied, respectively, for PubMED/Cochrane Library and Embase. The review process followed the Preferred Reporting Items for Systematic Reviews and Meta-analysis (PRISMA) statement guidelines [15]. Inclusion criteria followed the PICOS items: participants, interventions, comparisons, outcomes, and study design. Participants $(P)$ must have adenocarcinoma of the prostate and have at least one of the following high-risk features:

1. Clinical (c) T stage $\geq 2 \mathrm{c}$ and/or initial PSA $\geq 15 \mathrm{ng} / \mathrm{ml}$ and/or biopsy GS $\geq 8$ (high grade) or any cT stage and $\mathrm{CN} 1$

2. Pathological ( $p$ ) T stage $>2$ and/or $p G S \geq 8$ (high grade) and/or positive surgical margins and/or pN1

3. Detectable PSA after radical prostatectomy (RP) or PSA nadir $>2 \mathrm{ng} / \mathrm{ml}$ after EBRT 
4. High risk of postoperative pathological features (point 3) or high risk for progression or cancer-related death

The intervention (I) was defined as a combination of primary treatment (RP or EBRT) and systemic neoadjuvant, concomitant, or adjuvant therapies. Regarding comparative studies (C), we accepted those with the following characteristics: primary treatment versus primary treatment combined with adjuvant, neoadjuvant, or concomitant therapy; comparison of two multimodal treatments; and comparison of different adjuvant or neoadjuvant schedules. The scope of our review was broad in order to overview the recent literature in the field. Primary outcomes (O) were OS/overall mortality, cancer-specific survival/CSM, disease recurrence, and progression. Secondary outcomes remained undefined to respect the broad scope of the review and permit the assessment of future perspectives. We selected prospective studies $(S)$ including pilot studies-phases 1, 2, 3, and 4. Ongoing trials were also included to describe future perspectives. Terminated studies were included because these might also contain relevant information (eg, termination for high toxicity rates).

We used exclusion criteria following the PICOS scheme: $\mathrm{P}$ - prostate cancer different from adenocarcinoma; cT < 2c with the exception of cT2 if not better specified; in vitro, ex vivo, or animal experiments; I - brachytherapy and proton therapy; $\mathrm{C}$ - primary treatment with adjuvant or neoadjuvant therapy versus systemic treatment alone, comparison of different primary treatments, quality of life; $\mathrm{O}$ - specific exclusion criteria were not applied; $\mathrm{S}-$ metaanalyses, pooled data, post hoc analyses, observational prospective studies, retrospective studies or lack of information on the study typology, and withdrawn studies. Screening of titles and abstracts was done by a single author, and the final selection of studies was based on a collegial consensus. The risk of bias assessment followed the Cochrane recommendations (Higgins JPT, Green S [editors]; Cochrane Handbook for Systematic Reviews of Interventions Version 5.1.0 (updated March 2011) and the Cochrane Collaboration 2011; available from http://handbook.cochrane.org).

\section{Evidence synthesis}

From 11406 items, we finally obtained 77 studies for the qualitative review (PRISMA flow diagram in Fig. 1). We summarized the review results in a narrative way. The main results of the review are reported in Table 1-3; complete details of the ongoing trials are shown in Table 4 and 5 . The risk of bias was assessed only for randomized controlled trials (RCTs) and not for comparative nonrandomized trials considering the presence of a single nonrandomized comparative study (Supplementary Table 1).

\subsection{ADT and radiotherapy}

The combination of first-generation ADT with EBRT has been studied extensively during the last decades in phase 3 RCTs, including some studies already published before the period considered by this review (Supplementary Table 2). In the neoadjuvant setting, two main studies assessed the survival effect of luteinizing hormone-releasing hormone (LHRH) agonists + EBRT versus EBRT alone: RTOG 8610 [16] found that 4 mo of neoadjuvant goserelin $3.6 \mathrm{mg}$ improved CSM compared with EBRT alone, and these results were confirmed by the TROG 96.01 trial with $10 \mathrm{yr}$ CSM rates of $22.0 \%$ for EBRT without neoadjuvant ADT, and $18.9 \%$ and 
$11.4 \%$ for 3 and 6 mo neoadjuvant ADT, respectively (Supplementary Table 2) [17]. The EORTC 22863 phase 3 trial [5] also demonstrated the benefit of concomitant-adjuvant long-term (3 yr) ADT compared with EBRT alone, reaching 10-yr disease-free survival (DFS) rates of $47.7 \%$ versus $22.7 \%$ and OS rates of $58.1 \%$ versus $39.8 \%$ (Supplementary Table 2 ). In the NCT00116220 trial [18], 6 mo of LHRH agonist + flutamide $250 \mathrm{mg}$ three times a day in association with EBRT showed 8-yr OS rates of $74 \%$ for this treatment versus $61 \%(p=0.01)$ with EBRT alone. The effect of long-term ADT was assessed in the RTOG 8531 trial [19], which evaluated CSM when goserelin $3.6 \mathrm{mg}$ was added from the last week of radiotherapy until disease progression compared with salvage ADT resulting, respectively, in OS and CSM that favored the adjuvant arm (Supplementary Table 2). RTOG 9202 [20,21] and EORTC 22961 [22] assessed DFS and overall mortality, respectively, when long-term adjuvant ADT was added to EBRT. In the RTOG 9202 trial, 2 yr of adjuvant goserelin $3.6 \mathrm{mg}$ after primary EBRT showed improved 15-yr DFS and CSS with a risk reduction of 30\%, but no difference for other-cause mortality (Supplementary Table 2) [20,23]. EORTC 22961 showed improved 5-yr CSM rates in the 3-yr adjuvant ADTarm compared with 6-mo ADT (3.2\% vs $4.7 \%)$ and 5 -yr overall mortality rates, respectively, of $15.2 \%$ and $19 \%$ ( $p=0.65$ for noninferiority; Supplementary Table 2) [22]. Intermittent adjuvant LHRH analog did not demonstrate any difference compared with 5-yr continuous treatment in terms of biochemical recurrence-free survival (BRFS) and also for noninferiority [24] (Table 1). The PCSIV trial (NCT00223171) [25] assessed OS for patients treated with primary EBRT, randomizing them to the 36- or 18-mo adjuvant ADT; final results showed overlapping 10 -yr OS of $62.4 \%$ versus $62.0 \%$ (Table 1 ). The NCT00116220 trial $[18,26]$ compared 6-mo EBRT + ADT versus EBRT alone, showing, after $16.6 \mathrm{yr}$ of median follow-up, OS rates of $31 \%(95 \% \mathrm{Cl} 20.52-41.09)$ for EBRT alone versus $44 \%$ (95\% Cl $32.41-54.56)$ for EBRT with ADT in the subgroup of patients with absence or minimal cardiovascular comorbidity. This result was inverted for patients with moderate to severe comorbidities. SPCG6 studied patients with localized and locally advanced prostate cancer randomizing them to bicalutamide $150 \mathrm{mg}$ versus placebo after different types of primary treatment (EBRT, RP, watchful waiting). Bicalutamide or placebo lasted until progression. After a follow-up of almost $15 \mathrm{yr}$, the treatment arm improved OS (HR 0.77; 95\% $\mathrm{Cl} 0.63-0.94, \mathrm{p}=0.01$ ) compared with the control arm for locally advanced patients [27].

\section{2. $\quad$ ADT and RP}

Neoadjuvant and adjuvant ADT have been tested with prostatectomy in men with high-risk prostate cancer. Available results showed no difference in biochemical recurrence, but the studies were not statistically powered to determine any survival benefit in OS compared with patients treated by surgery alone and the follow-ups were not long enough [28]. Recently, degarelix, an LHRH antagonist, was tested before surgery compared with degarelix + bicalutamide versus LHRHa + bicalutamide in patients with intermediate/high-risk features. No difference $(p=0.449)$ in pTO rates was apparent between the arms in this randomized phase 2 study [29]. Previous data [30] showed that the administration of adjuvant ADT (goserelin $3.6 \mathrm{mg}$ or bilateral orchiectomy) after RP for patients with lymph-node involvement increases progression-free survival ( $H R$ 3.42; $95 \% \mathrm{Cl} 1.96-5.98 ; p<0.0001$ ), but the study did not achieve the expected sample size for this endpoint (primary endpoint). Interestingly, ADT was shown to increase OS and prostate cancer - specific survival, which were secondary endpoints [30]. The recent CU 1005 trial was an open-label, randomized, noninferiority phase 2 trial that included 209 high-risk prostate cancer patients after surgery. It compared 9-mo 
adjuvant LHRHa + bicalutamide $50 \mathrm{mg} / \mathrm{d}$ with bicalutamide $150 \mathrm{mg} / \mathrm{d}$ to assess BRFS. The combination arm resulted in improved BRFS compared with bicalutamide alone [31] after a median follow-up of about $2 \mathrm{yr}$ (Table 2). There are still no long-term or conclusive results about the use of adjuvant ADT in patients with high-risk prostate cancer without lymph-node invasion, and confirmative trials are needed to support this indication. From this perspective, PRIORITI (NCT01753297) and AFU/GETUG 20/0310 (NCT01442246) trials are ongoing to evaluate adjuvant ADT after prostatectomy (Table 5). RADICALS-HD (NCT00541047) included $>2800$ patients in the phase 3 trial that has been assessing cancer-specific survival; patients who needed adjuvant radiotherapy after surgery were randomized to EBRT or EBRT + 6-mo ADT or EBRT + 24 mo ADT, and results are expected in the near future.

\subsection{Taxanes}

Early-phase trials have analyzed the pharmacokinetic profile and safety of taxanes + ADT (NCT01420250) combinations [32 - 34], demonstrating treatment feasibility in men with localized disease (Table 4). Three trials have shown a benefit adding docetaxel to ADT plus EBRT in high-risk localized prostate cancer, as evidenced by increasing biochemical-free survival - variably defined in RTOG0521, GETUG12, and in STAMPEDE MO cohorts. Longerterm follow-up is required and planned to define the clinical relevance of these findings in terms of metastasis-free survival (MFS) [35] and OS. The GETUG-12 phase 3 trial [36,37] randomized 413 patients with high-risk disease to $3 \mathrm{yr}$ of goserelin $10.8 \mathrm{mg}$ alone or combined with four cycles of docetaxel $70 \mathrm{mg} / \mathrm{m}^{2}+$ estramustine $10 \mathrm{mg} / \mathrm{kg} / \mathrm{d}$ given every 3 wk. Both EBRT and RP were possible local treatments, and they were given in $87 \%$ and $5 \%$ of men, respectively ( $7 \%$ of men with lymph-node invasion had no local therapy). The 8-yr relapse-free survival was $62 \%$ in the chemohormonal group and $50 \%$ in the ADT group ( $p=0.017$ ), demonstrating superiority for the combined therapy over ADT alone (Table 3 ). Long-term analysis of MFS and OS is planned.

STAMPEDE [12] is a multiarm, multistep trial that assessed failure-free survival and OS in patients with metastatic and nonmetastatic prostate cancer. The nonmetastatic subgroup was characterized by at least two of the following unfavorable features: cT3 - 4, bGS 8 - 10, and PSA $\geq 40 \mathrm{ng} / \mathrm{ml}$. Patients were originally randomized to different arms: (1) standard of care (SOC) defined as ADT for at least $2 \mathrm{yr}$, (2) SOC + docetaxel, (3) SOC + zoledronic acid, and (4) SOC + docetaxel and zoledronic acid. In the docetaxel comparison, 1145 patients had nonmetastatic disease of whom $62 \%$ had a planned EBRT (EBRT was made mandatory for men with localized disease since 2011). Docetaxel improved failure-free survival over SOC in the nonmetastatic subgroup ( $\mathrm{HR} 0.60,95 \% \mathrm{Cl} 0.45-0.80 ; \mathrm{p}=0.283 \times 10^{-3}$ ). OS data are immature and will be assessed in the coming years (Table 1). RTOG 0521 [38] randomized patients to receive docetaxel + ADT or ADT alone after EBRT: preliminary data were presented in congress and supported a $4 \%$ higher OS rate favoring the chemotherapy arm (one sided $p=0.03$; Table 1). The DFCl 05-043 phase 3 trial (NCT00116142) is assessing OS in patients treated with EBRT + ADT comparing concomitant docetaxel with primary treatment alone. A recent metaanalysis [13] assessed the role of docetaxel + SOC versus SOC to improve failure-free survival; data from four published and unpublished RCTs (GETUG-12, STAMPEDE, TAX3501, and RTOG 0521) showed an absolute improvement in failure-free survival for the treatment arm in these high-risk prostate cancer cohorts (HR 0.70, 95\% Cl $0.61-0.81, p<0.0001)$. In all these randomized trials, OS results are immature due to the limited number of deaths. Two unpublished phase 3 trials have tested docetaxel after prostatectomy. SPCG12 [39] 
randomized 459 patients after prostatectomy to six cycles of docetaxel or surveillance. The median follow-up was 56.8 mo. No improvement in biochemical DFS (Table 2), defined as a rising PSA of $>0.5 \mathrm{ng} / \mathrm{ml}$, was demonstrated. The lack of combination of docetaxel to ADT in this trial and the inclusion of patients not classically considered as very high risk for relapse (eg, those with pT2, Gleason 7 cancers) may explain these negative findings. The rather small VA CSP\#553 trial [40] showed no significant improvement in progression-free survival, after a median follow-up of 62.4 mo, when 18 wk of docetaxel was added to SOC compared with SOC alone, possibly because the trial was lacking statistical power (Table 2). Two other studies are currently evaluating the role of taxanes in men with high-risk disease. PEACE-2 is a European randomized phase 3 factorial design trial testing cabazitaxel and pelvic EBRT + ADT in men with very high-risk prostate cancer. The planned sample size is 1048 patients, and the trial is accruing patients in France, Spain, and Belgium (Table 4) [41]. The PUNCH 90203 trial (NCT00430183) randomized 750 men with high-risk disease to six cycles of neoadjuvant docetaxel + LHRH agonist + prostatectomy versus prostatectomy alone, with biochemical progression-free survival as the primary endpoint. The final data collection date for primary outcome measure is foreseen for October 2018 (Table 5).

\subsection{Other chemotherapy agents}

All trials testing chemotherapy compounds other than docetaxel have reported negative findings. The SWOG 9921 trial randomized 983 patients after RP to mitoxantrone + ADT ( $2 \mathrm{yr}$ goserelin + bicalutamide) versus ADT alone, but the study was terminated early due to an excess of acute myelogenous leukemia (three cases). Long-term follow-up (median $11 \mathrm{yr}$ ) results indicate no OS benefit $(p=0.74)$ for mitoxantrone + ADT (OS 87\%) compared with ADT alone (86\%) [42]. RTOG 9902 [43] randomized patients who underwent EBRT and ADT to receive multiagent chemotherapy (estramustine $280 \mathrm{mg}+$ etoposide $50 \mathrm{mg} / \mathrm{m}^{2}+$ paclitaxel $135 \mathrm{mg} / \mathrm{m}^{2}$ ); the trial was also terminated for excess of thromboembolic toxicity. No OS improvement was observed (Table 1).

\subsection{Bisphosphonates}

PR04 (ISRTN61384873) [44] was a phase 3 trial involving 508 patients who were treated with $520 \mathrm{mg} / \mathrm{d}$ of sodium clodronate versus placebo, with local treatment consisting of EBRT in approximately $70 \%$. The study included 254 patients per arm with cT2 - 4NO - N1 prostate cancer. After a median follow-up of $12 \mathrm{yr}$, there was no difference in OS between the study groups (HR 1.12, 95\% Cl $0.89-1.42, \mathrm{p}=0.94$ ). More recently, in the STAMPEDE trial, SOC was tested with or without zoledronic acid [12]; in the nonmetastatic subgroup, no benefit was shown with zoledronic acid use (HR 1.08, 95\% Cl 0.66 - 1.76; Table 1). The ZEUS trial [45] aimed to prevent the onset of bone metastases in castration-naïve patients with high-risk features for metastatic progression (GS $8-10$ and/or PSA $\geq 20 \mathrm{ng} / \mathrm{ml}$ and/or pN1), with or without primary treatment. After a median follow-up of $4.8 \mathrm{yr}$, in the subgroup of patients who underwent primary curative treatment, no improvement was demonstrated (43\% vs $38 \%$ metastatic events; $p=0.66$ ). The TROG 03.04/RADAR study randomized patients (cT2a and bGS $7-10, P S A \geq 10 \mathrm{ng} / \mathrm{ml}$ or CT2b-4, NO, MO) to 6-mo neoadjuvant ADT with or without 12 mo adjuvant ADT, and both with or without 18-mo adjuvant zoledronic acid. One-year adjuvant ADT was beneficial for CSM (HR 0.70 [0.50, 0.97]; $p=0.035)$ and distant progression (HR $0.71[0.56,0.90] ; p=0.004)$. However, there was no significant influence of zoledronic acid on any outcome after a median follow-up of $10.4 \mathrm{yr}$ [46]. These data are supported by a 
meta-analysis [13] showing no survival benefit when bisphosphonates are added to SOC (HR $1.03,95 \% \mathrm{Cl} 0.89-1.18, \mathrm{p}=0.724$ ) compared with SOC alone, even when zoledronic acid was considered independently ( $\mathrm{HR} 0.98 ; 95 \% \mathrm{Cl} 0.82-1.16, \mathrm{p}=0.782$ ).

\subsection{Next-generation androgen receptor pathway inhibitors}

Novel androgen receptor pathway inhibitors are approved for the treatment of men with metastatic CRPC. In castration-naïve patients, these compounds can affect androgenregulated tumor cells more effectively than previous molecules, which had insufficient androgen-receptor inhibition properties. From this perspective, LATITUDE and STAMPEDE trials showed that abiraterone $1000 \mathrm{mg} / \mathrm{d}+$ prednisone/prednisolone $5 \mathrm{mg} / \mathrm{d}+\mathrm{ADT}$ increased OS compared with placebo + ADT in metastatic castration-naïve patients $[47,48]$. It is still unclear if abiraterone has a significant impact on OS in combination with local treatment for high-risk, non-metastatic disease; however, results from a prespecified analysis of STAMPEDE in the subgroup of patients with planned radiotherapy showed a positive effect on failure-free survival for the abiraterone arm [48]. Recently, a phase 2 study showed that 12 wk of abiraterone + LHRHa decreased the intraprostatic androgen level more efficaciously than LHRHa alone, and that long exposure (12 vs $24 \mathrm{wk}$ ) to abiraterone + LHRHa increased the proportion of pathological complete response (pCR) from $4 \%$ to $10 \%$ [49]. Enzalutamide was also studied in the neoadjuvant setting (24-wk treatment) showing no $\mathrm{PCR}$ in the enzalutamide-alone arm but $4.3 \% \mathrm{pCR}$ in association with dutasteride + LHRHa [50]. These results suggest that longer and more intense $A D T$ can drive a stronger molecular and pathological response. Based on these assumptions, various phase 3 trials are studying the role of new-generation androgen receptor pathway inhibitors next to primary treatment. The ENZARAD trial (NCTO2446444) is recruiting patients to assess the role of enzalutamide when combined with ADT and EBRT (Table 4). Recently the ATLAS (NCT02531516) study has started recruiting patients to randomly receive apalutamide (ARN-509), a second-generation androgen receptor pathway inhibitor, together with LHRH agonist + EBRT (NCT02531516) with MFS as the primary endpoint (Table 4).

\subsection{Discussion and limitations}

High-quality RCTs showed that EBRT + ADT prolongs survival in the neoadjuvant-concomitant $[16,17]$, neoadjuvant-concomitant-adjuvant $[18,20,21,23,26]$, and concomitant-adjuvant $[5,19,22,27]$ settings. In general, the current evidence supports the following: (1) any ADT duration is better than no ADT [5,16 - 18], (2) long-term ADT (eg, $3 \mathrm{yr}$ ) is slightly better in OS than a short duration (6 mo) [22], but (3) it remains unknown whether a duration of <3yr [25] In some patients or $>3 \mathrm{yr}$ in very high-risk patients is more appropriate. Hypothetically, the association of second-generation androgen receptor pathway inhibitors with EBRT can result in an added benefit for patients, especially those at a high risk of micrometastatic disease. From this perspective, abiraterone (STAMPEDE [48]), enzalutamide (ENZARAD), and apalutamide (ATLAS) are currently under investigation to treat high-risk prostate cancer, but definitive survival results are still pending. In some models, chemotherapy administered simultaneously with ADT may increase efficacy compared with the two treatments administered in sequence [9]. Considering that ADT is a known radiosensitizer [8], it is hypothesized that the combination of chemotherapy and ADT in men treated locally with radiation may improve their outcome. Three randomized trials (GETUG 12, RTOG 0521, and STAMPEDE) and a meta-analysis [13] have currently available data in the field showing better relapse-free survival for docetaxel in combination with EBRT + ADT compared with EBRT + ADT 
alone. However, most guidelines do not support routine use of chemotherapy in high-risk prostate cancer because relapse-free survival, including PSA recurrence as an event, has not been considered sufficient to justify the use of such combination. Clinical relapse-free survival, MFS, and OS results are expected in the near future. Chemotherapy, in combination with prostatectomy, has not been associated with improved outcomes. VACSP\#553 trial [40] and SPCG12 did not demonstrate any benefit for docetaxel after RP [39], and no recurrence-free survival benefit was shown for docetaxel + degarelix at $1 \mathrm{yr}$ when compared with degarelix alone in the neoadjuvant setting [51]. Neoadjuvant ADT + RP is not recommended by international guidelines as a result of the lack of OS improvement in the settings where it was studied, mostly intermediate- or moderately high-risk disease [28]. However, reinforced androgen receptor pathway inhibition may improve outcomes in the neoadjuvant or adjuvant settings for patients with truly high-risk disease considering the positive survival results from LATITUDE [47] and STAMPEDE [48] in men with castration-naïve metastatic disease. Earlyphase studies are ongoing to assess the potentialities of neoadjuvant abiraterone, apalutamide, and enzalutamide. The CU 1005 trial [31] showed improved biochemical relapsefree survival for high-risk patients treated with LHRHa + bicalutamide $50 \mathrm{mg}$ compared with bicalutamide $150 \mathrm{mg}$ alone, but hard endpoints are needed to demonstrate a consistent survival benefit. The role of adjuvant ADT after surgery in patients with no lymph-node invasion still remains an open question. One RCT included 352 patients with $\mathrm{pT} 3-4$ disease, without lymph-node invasion, to assess relapse-free survival as the primary endpoint [52] for patients treated with adjuvant flutamide $250 \mathrm{mg}$ three times a day, compared with no adjuvant therapy. This study showed a significant improvement for the treatment arm (HR $0.51,95 \% \mathrm{Cl} 0.32-0.81$; median follow-up $72 \mathrm{mo}$ ). However, there are still no long-term survival data, and new results are expected from the AFU-GETUG 20 and PRIORITI trials. The variability of high-risk prostate cancer definitions in the literature, and the combination of intermediate- and high-risk patients in several studies limited the inclusion of several trials in our review. The variability in outcome definitions (Supplementary Table 3 ) is also a limitation.

\section{Conclusions}

Treatment of high-risk prostate cancer is a field in evolution, with promising results for multimodal therapies next to EBRT or RP as primary therapies. The association of ADT with EBRT clearly improves results compared with EBRT alone. However, there is still a lack of evidence regarding a survival benefit when ADT is associated with RP and further studies are needed to assess this point, especially with novel compounds. Phase 3 trials assessing docetaxel-based chemotherapy in men with high-risk prostate cancer are maturing, and data on clinical relapse-free survival, MFS, and OS are expected soon. Next-generation androgen receptor pathway inhibitors are currently being tested in combination with primary treatment with promising preliminary results. 


\section{References}

[1] Torre LA, Bray F, Siegel RL, Ferlay J, Lortet-Tieulent J, Jemal A. Global cancer statistics, 2012.

CA Cancer J Clin 2015;65:87-108.

[2] Mottet N, Bellmunt J, Bolla M, et al. EAU-ESTRO-SIOG guidelines on prostate cancer, Part

1: screening, diagnosis, and local treatment with curative intent. Eur Urol 2017;71:618-29.

[3] Horwich A, Hugosson J, de Reijke T, et al. Prostate cancer: ESMO Consensus Conference Guidelines 2012. Ann Oncol 2013;24:1141-62.

[4] Rider JR, Sandin F, Andrén O, Wiklund P, Hugosson J, Stattin P. Longterm outcomes among noncuratively treated men according to prostate cancer risk category in a nationwide, population-based study. Eur Urol 2013;63:88-96.

[5] Bolla $M$, Van Tienhoven $G$, Warde $P$, et al. External irradiation with or without long-term androgen suppression for prostate cancer with high metastatic risk: 10 -year results of an EORTC randomized study. Lancet Oncol 2010;11:1066-73.

[6] Yossepowitch O, Eggener SE, Serio AM, et al. Secondary therapy, metastatic progression, and cancer specific mortality in men with clinically high-risk prostate cancer treated with radical prostatectomy. Eur Urol 2008;53:950-9.

[7] Deng Q, Tang DG. Androgen receptor and prostate cancer stem cells: biological mechanisms and clinical implications. Endocr Relat Cancer 2015;22:T209-20.

[8] Bartek J, Mistrik M, Bartkova J. Androgen receptor signaling fuels DNA repair and radioresistance in prostate cancer. Cancer Discov 2013;3:1222-4.

[9] Eigl BJ, Eggener SE, Baybik J, et al. Timing is everything: preclinical evidence supporting simultaneous rather than sequential chemohormonal therapy for prostate cancer. Clin Cancer Res 2005;11:4905-11.

[10] Gravis G, Boher JM, Joly F, et al. Androgen deprivation therapy (ADT) plus docetaxel versus ADT alone in metastatic non castrate prostate cancer: impact of metastatic burden and long-term survival analysis of the randomized phase 3 GETUG-AFU15 trial. Eur Urol 2016;70:256-62.

[11] Sweeney $\mathrm{CJ}$, Chen $\mathrm{YH}$, Carducci $M$, et al. Chemohormonal therapy in metastatic hormonesensitive prostate cancer. N Engl J Med 2015;373:737-46.

[12] James ND, Sydes MR, Clarke NW, et al. Addition of docetaxel, zoledronic acid, or both to first-line long-term hormone therapy in prostate cancer (STAMPEDE): survival results from an adaptive, multiarm, multistage, platform randomised controlled trial. Lancet 2016;387:116377.

[13] Vale CL, Burdett S, Rydzewska LH, et al. Addition of docetaxel or bisphosphonates to standard of care in men with localised or metastatic, hormone-sensitive prostate cancer: a systematic review and meta-analyses of aggregate data. Lancet Oncol 2016;17:243-56.

[14] Gillessen S, Attard G, Beer TM, et al. Management of patients with advanced prostate cancer: the report of the Advanced Prostate Cancer Consensus Conference APCCC 2017. Eur Urol 2018;73:178-211.

[15] Moher D, Liberati A, Tetzlaff J, Altman DG. PRISMA Group. Preferred reporting items for systematic reviews and meta-analyses: the PRISMA statement. Int J Surg 2010;8:336-41.

[16] Roach III M, Bae K, Speight J, et al. Short-term neoadjuvant androgen deprivation therapy and external-beam radiotherapy for locally advanced prostate cancer: long-term results of RTOG 8610. J Clin Oncol 2008;26:585-91.

[17] Denham JW, Steigler A, Lamb DS, et al. Short-term neoadjuvant androgen deprivation and radiotherapy for locally advanced prostate cancer: 10-year data from the TROG 96.01 randomised trial. Lancet Oncol 2011;12:451-9. 
[18] D'Amico AV, Chen MH, Renshaw AA, Loffredo M, Kantoff PW. Androgen suppression and radiation vs radiation alone for prostate cancer: a randomized trial. JAMA 2008;299:289-95. [19] Pilepich MV, Winter K, Lawton CA, et al. Androgen suppression adjuvant to definitive radiotherapy in prostate carcinoma-longterm results of phase III RTOG 85-31. Int J Radiat Oncol Biol Phys 2005;61:1285-90.

[20] Lawton CAF, Dignam JJ, Hanks GE, et al. Duration of androgen deprivation in locally advanced prostate cancer: long-term update of NRG oncology/RTOG 9202. Int J Radiat Oncol Biol Phys 2015;93 (3 Suppl):S44.

[21] Horwitz EM, Bae K, Hanks GE, et al. Ten-year follow-up of radiation therapy oncology group protocol 92-02: a phase III trial of the duration of elective androgen deprivation in locally advanced prostate cancer. J Clin Oncol 2008;26:2497-504.

[22] Bolla M, de Reijke TM, Van Tienhoven G, et al. Duration of androgen suppression in the treatment of prostate cancer. N Engl J Med 2009;360:2516-27.

[23] Lawton CAF, Lin X, Hanks GE, et al. Duration of androgen deprivation in locally advanced prostate cancer: long-term update of NRG oncology RTOG 9202. Int J Radiat Oncol Biol Phys 2017;98:296-303.

[24] Ito K, Suzuki K, Yamanaka H. Oncological outcomes in patients with locally advanced prostate cancer treated with neoadjuvant endocrine and external beam radiation therapy followed by adjuvant continuous/intermittent endocrine therapy in an open-label, randomized, phase III trial. Eur Urol Suppl 2016;15:e677.

[25] Nabid A, Garant MP, Martin AG, et al. Duration of androgen deprivation therapy in high risk prostate cancer: final results of a randomized phase III trial. J Clin Oncol 2017;35(15_Suppl):5008.

[26] D'Amico AV, Chen MH, Renshaw A, Loffredo M, Kantoff PW. Longterm follow-up of a randomized trial of radiation with or without androgen deprivation therapy for localized prostate cancer. JAMA 2015;314:1291-3.

[27] Thomsen FB, Brasso K, Christensen IJ, et al. Survival benefit of early androgen receptor inhibitor therapy in locally advanced prostate cancer: long-term follow-up of the SPCG-6 study. Eur J Cancer 2015;51:1283-92.

[28] Kumar S, Shelley M, Harrison C, Coles B, Wilt TJ, Mason MD. Neoadjuvant and adjuvant hormone therapy for localised and locally advanced prostate cancer. Cochrane Database Syst Rev 2006;4: CD006019.

[29] Sayyid RK, Evans A, Hersey K, et al. A phase II, randomized, openlabel study of neoadjuvant degarelix versus LHRH agonist in prostate cancer patients prior to radical prostatectomy. Clin Cancer Res 2017;23:1974-80.

[30] Messing EM, Manola J, Yao J, et al. Immediate versus deferred androgen deprivation treatment in patients with node-positive prostate cancer after radical prostatectomy and pelvic lymphadenectomy. Lancet Oncol 2006;7:472-9.

[31] Chang K, Qin XJ, Zhang HL, et al. Comparison of two adjuvant hormone therapy regimens in patients with high-risk localized prostate cancer after radical prostatectomy: primary results of study CU1005. Asian J Androl 2016;18:452-5.

[32] Chen RC, Rosenman JG, Hoffman LG, et al. Phase I study of concurrent weekly docetaxel, high-dose intensity-modulated radiation therapy (IMRT) and androgen-deprivation therapy (ADT) for high-risk prostate cancer. BJU Int 2012;110:721-6.

[33] Marshall DT, Ramey S, Golshayan AR, Keane TE, Kraft AS, Chaudhary U. Phase I trial of weekly docetaxel, total androgen blockade, and image-guided intensity-modulated 
radiotherapy for localized high-risk prostate adenocarcinoma. Clin Genitourin Cancer 2014;12:80-6.

[34] Bolla M, Hannoun-Levi JM, Ferrero JM, et al. Concurrent and adjuvant docetaxel with three-dimensional conformal radiation therapy plus androgen deprivation for high-risk prostate cancer: preliminary results of a multicentre phase II trial. Radiother Oncol 2010;97:312-7.

[35] XieW, Regan MM, Buyse $M$, et al. Metastasis-free survival is a strong surrogate of overall survival in localized prostate cancer. J Clin Oncol 2017;35:3097-104.

[36] Fizazi K, Lesaunier F, Delva R, et al. A phase III trial of docetaxelestramustine

in high-risk localised prostate cancer: a planned analysis of response, toxicity and quality of life in the GETUG 12 trial. Eur J Cancer 2012;48:209-17.

[37] Fizazi K, Faivre L, Lesaunier F, et al. Androgen deprivation therapy plus docetaxel and estramustine versus androgen deprivation therapy alone for high-risk localised prostate cancer (GETUG 12): a phase 3 randomised controlled trial. Lancet Oncol 2015;16:787-94.

[38] Sandler HM, Hu C, Rosenthal SA, et al. A phase III protocol of androgen suppression (AS) and 3DCRT/IMRT versus AS and 3DCRT/IMRT followed by chemotherapy (CT) with docetaxel and prednisone for localized, high-risk prostate cancer (RTOG 0521). J Clin Oncol 2015;33(Suppl):LBA5002.

[39] Ahlgren G, Flodgren P, Tammela TL, et al. A randomized phase III trial between adjuvant docetaxel and surveillance after radical prostatectomy for high risk prostate cancer: Results of SPCG12. J Clin Oncol 2016;34(Suppl):5001.

[40] Lin D, Garzotto M, Aronson W, et al. VA CSP\#553 chemotherapy after prostatectomy (cap) for high risk prostate carcinoma: a phase III randomized study. J Urol 2016;195(4 Suppl):e1071. [41] Fizazi K, Abrahamsson PA, Ahlgren G, et al. Achievements and perspectives in prostate cancer phase 3 trials from genitourinary research groups in Europe: introducing the Prostate Cancer Consortium in Europe. Eur Urol 2015;67:904-12.

[42] Glode LM, Tangen CM, Hussain $M$, et al. Adjuvant androgen deprivation (ADT) versus mitoxantrone plus prednisone (MP) plus ADT in high-risk prostate cancer ( $P C a$ ) patients following radical prostatectomy: a phase III intergroup trial (SWOG S9921) NCTO0004124. J Clin Oncol 2017;35(6 Suppl):2.

[43] Rosenthal SA, Hunt D, Sartor AO, et al. A phase 3 trial of 2 years of androgen suppression and radiation therapy with or without adjuvant chemotherapy for high-risk prostate cancer: final results of Radiation Therapy Oncology Group phase 3 randomized trial NRG Oncology RTOG 9902. Int J Radiat Oncol Biol Phys 2015;93:294-302.

[44] Dearnaley DP, Mason MD, Parmar MK, Sanders K, Sydes MR. Adjuvant therapy with oral sodium clodronate in locally advanced and metastatic prostate cancer: long-term overall survival results from the MRC PR04 and PR05 randomised controlled trials. Lancet Oncol
2009;10:872-6.

[45] Wirth M, Tammela T, Cicalese V, et al. Prevention of bone metastases in patients with high-risk nonmetastatic prostate cancer treated with zoledronic acid: efficacy and safety results of the Zometa European Study (ZEUS). Eur Urol 2015;67:482-91.

[46] Joseph DJ, Lamb DS, Denham JW, Oldmeadow C, Attia J, Steigler A. Ten year final results of the TROG 03.04 (RADAR) randomised phase 3 trial evaluating duration of androgen suppression _zoledronate for locally advanced prostate cancer. J Clin Oncol 2018;36(Suppl 6S):1.

[47] Fizazi K, Tran N, Fein L, et al. Abiraterone plus prednisone in metastatic, castrationsensitive prostate cancer. N Engl J Med 2017;377:352-60. 
[48] James ND, de Bono JS, Spears MR, et al. Abiraterone for prostate cancer not previously treated with hormone therapy. N Engl J Med 2017;377:338-51.

[49] Taplin ME, Montgomery B, Logothetis $\mathrm{CJ}$, et al. Intense androgendeprivation therapy with abiraterone acetate plus leuprolide acetate in patients with localized high-risk prostate cancer: results of a randomized phase II neoadjuvant study. J Clin Oncol 2014;32:3705-15.

[50] Montgomery B, Tretiakova MS, Joshua AM, et al. Neoadjuvant enzalutamide prior to prostatectomy. Clin Cancer Res 2017;23:2169-76.

[51] Nosov A, Reva S, Protsenko S, Buevich N, Veliev E, Petrov S. Safety and efficacy of neoadjuvant chemohormonal and hormonal treatment followed by radical prostatectomy for patients with high- and very high risk prostate cancer: Initial results of prospective, randomized, phase III clinical trial. Eur Urol Suppl 2016;15:e1193.

[52] Wirth MP, Weissbach L, Marx FJ, et al. Prospective randomized trial comparing flutamide as adjuvant treatment versus observation after radical prostatectomy for locally advanced, lymph node-negative prostate cancer. Eur Urol 2004;45:267-70.

[53] Corn PG, Song DY, Heath E, et al. Sunitinib plus androgen deprivation and radiation therapy for patients with localized high-risk prostate cancer: results from a multi-institutional phase 1 study. Int J Radiat Oncol Biol Phys 2013;86:540-5.

[54] Azria D, Rebillard X, Coux N, et al. Concurrent treatment with everolimus (RAD001) and hormonoradiotherapy in high-risk locally advanced prostate cancer: results of a phase I trial. J Clin Oncol 2013;31(6_Suppl):150.

[55] Carles J, Nogue M, Sole JM, et al. Phase II study of vinorelbine and estramustine in combination with conformational radiotherapy for patients with high-risk prostate cancer. Int J Radiat Oncol Biol Phys 2010;76:1085-91.

[56] Mason MD, Clarke NW, James ND, et al. Adding celecoxib with or without zoledronic acid for hormone-naïve prostate cancer: longterm survival results from an adaptive, multiarm, multistage, platform, randomized controlled trial. J Clin Oncol 2017;35:1530-41.

[57] Berglund RK, Tangen CM, Powell IJ, et al. Ten-year follow-up of neoadjuvant therapy with goserelin acetate and flutamide before radical prostatectomy for clinical T3 and T4 prostate cancer: update on Southwest Oncology Group Study 9109. Urology 2012;79:633-7.

[58] Maddox M, Layton J, Angela T, Anthony M, Renzulli II J. Feasibility of radical prostatectomy following neoadjuvant ixabepilone for high-risk prostate cancer: a phase II clinical trial. J Urol 2013;189: e314-5.

[59] Ross RW, Galsky MD, Febbo P, et al. Phase 2 study of neoadjuvant docetaxel plus bevacizumab in patients with high-risk localized prostate cancer: a Prostate Cancer Clinical Trials Consortium trial. Cancer 2012;118:4777-84.

[60] Ploussard G, Paule B, Salomon L, et al. Pilot trial of adjuvant paclitaxel plus androgen deprivation for patients with high-risk prostate cancer after radical prostatectomy: results on toxicity, side effects and quality-of-life. Prostate Cancer Prostatic Dis 2010;13:97-101.

[61] Saldana C, Salomon L, Rousseau B, et al. Weekly paclitaxel versus ADT alone in localized high-risk prostate cancer: results of a single institution phase II trial. J Clin Oncol 2015;33(7_Suppl):37.

[62] Hussain A, Wu Y, Mirmiran A, et al. Long-term follow-up of a prospective trial of trimodality therapy of weekly paclitaxel, radiation, and androgen deprivation in high-risk prostate cancer with or without prior prostatectomy. Int J Radiat Oncol Biol Phys
2012;82:167-74. 
[63] Kumar P, Van Veldhuizen P, Thompson M, Shen X, Pinski JK. Results of a phase I-II trial using trimodality therapy in patients with postprostatectomy high risk pathologic (p) T23NOMO prostate cancer. J Clin Oncol 2016;34(15_Suppl):e16620.

[64] Hurwitz MD, Harris J, Sartor O, et al. Adjuvant radiation therapy, androgen deprivation, and docetaxel for high-risk prostate cancer postprostatectomy: Results of NRG Oncology/RTOG study 0621. Cancer 2017;123:2489-96.

[65] Schweizer MT, Huang P, KattanMW, et al. Adjuvant leuprolide with or without docetaxel in patients with high-risk prostate cancer after radical prostatectomy (TAX-3501): important lessons for future trials. Cancer 2013;119:3610-8.

[66] Zurita AJ, Pisters LL, Wang X, et al. Integrating chemo-hormonal therapy and surgery in known or suspected lymph node metastatic prostate cancer. Prostate Cancer Prostatic Dis 2015;18:276-80.

[67] Thalgott $M$, Horn $T$, Heck $M M$, et al. Long-term results of a phase II study with neoadjuvant docetaxel chemotherapy and complete androgen blockade in locally advanced and high-risk prostate cancer. J Hematol Oncol 2014;7:1-9.

[68] Narita S, Tsuchiya N, Kumazawa T, et al. Short-term clinicopathological outcome of neoadjuvant chemohormonal therapy comprising complete androgen blockade, followed by treatment with docetaxel and estramustine phosphate before radical prostatectomy in Japanese patients with high-risk localized prostate cancer. World J Surg Oncol 2012;10:1-6. [69] Koie T, Ohyama C, Yamamoto $H$, et al. Safety and effectiveness of neoadjuvant luteinizing hormone-releasing hormone agonist plus low-dose estramustine phosphate in high-risk prostate cancer: a prospective single-arm study. Prostate Cancer Prostatic Dis 2012;15:397-
401.

[70] Silberstein JL, Poon SA, Sjoberg DD, et al. Long-term oncological outcomes of a phase II trial of neoadjuvant chemohormonal therapy followed by radical prostatectomy for patients with clinically localised, high-risk prostate cancer. BJU Int 2015;116:50-6.

[71] Dean JP, Montgomery RB, Wan J, et al. On-target activity of neoadjuvant cixutumumab and combined androgen deprivation therapy for high-risk prostate cancer: a phase II trial. J Clin Oncol 2011;29 (Suppl 7):153.

[72] Vuky J, Corman JM, Porter C, Olgac S, Auerbach E, Dahl K. Phase II trial of neoadjuvant docetaxel and CG1940/CG8711 followed by radical prostatectomy in patients with high-risk clinically localized prostate cancer. Oncologist 2013;18:687-8.

[73] Ross AE, Hughes RM, Glavaris $S$, et al. Pharmacodynamic and pharmacokinetic neoadjuvant study of hedgehog pathway inhibitor Sonidegib (LDE-225) in men with high-risk localized prostate cancer undergoing prostatectomy. Oncotarget 2017;8:104182-9.

[74] Guttilla A, Bortolus R, Giannarini G, et al. Multimodal treatment for high-risk prostate cancer with high-dose intensity-modulated radiation therapy preceded or not by radical prostatectomy, concurrent intensified-dose docetaxel and long-term androgen deprivation therapy: results of a prospective phase II trial. Radiat Oncol 2014;9:1-10.

[75] Valicenti RK, Trabulsi E, Intenzo C, Lavarino J, Xu Y, Chervoneva I. A Phase I trial of samarium-153-lexidronam complex for treatment of clinically non metastatic high-risk prostate cancer: first report of a completed study. Int J Radiat Oncol Biol Phys 2011;79:732-
7.

[76] Foro Arnalot P, Maldonado X, Bonet M. Chemoradiotherapy in highrisk prostate cancer (QRT SOGUG trial): preliminary report. Radiother Oncol 2016;119(Suppl 1):S157. 
[77] Singh NK, Bilusic M, Kim JW, et al. Randomized phase II clinical trial to assess MUC1 specific immune response to L-BLP25 vaccine in addition to standard therapy in newly diagnosed high-risk prostate cancer. J Clin Oncol 2012;30(15_Suppl):TPS4701.

[78] Rozet F, Habibian M, Berille J, et al. A phase III randomized, open label multicenter trial to evaluate the benefit of leuprorelin acetate for 24 months after radical prostatectomy in patients with high risk of recurrence (AFU-GETUG 20/0310). J Clin Oncol 2012;30 (5_Suppl):252.

[79] Ornstein MC, Stephenson AJ, Elson P, et al. Adjuvant enzalutamide (Enza) formenwith non-metastatic high-risk prostate cancer (HRPCa) after radical prostatectomy (RP). J Clin Oncol 2018;36(Suppl 6S):88.

[80] Guerif SG, Latorzeff I, Roca L, et al. The acute toxicity results of the GETUG-AFU 22 study: a multicenter randomized phase II trial comparing the efficacy of a short hormone therapy in combination with radiotherapy to radiotherapy alone as a salvage treatment for patients with detectable PSA after radical prostatectomy. J Clin Oncol 2017;35(6_Suppl):16. 
Table 1 - Summary of the results of clinical trials using systemic treatments together with EBRT as local treatment

\begin{tabular}{|c|c|c|c|c|c|c|c|}
\hline Reference & Phase & TT & Risk factors & EBRT & Arns & SS & Endpoints \\
\hline \multicolumn{8}{|l|}{$\begin{array}{l}\text { ADT } \\
\text { Por }\end{array}$} \\
\hline \multirow{5}{*}{$\begin{array}{l}\text { Bolla et al. [5] } \\
\text { EORTC 22863 }\end{array}$} & 3 & $\mathrm{CO}+\mathrm{AD}$ & cT1-2 + WHO G3 or $\mathrm{CT}^{-4}-4$ & EBRT & Arm 1: 3-yr goserelin $3.6 \mathrm{mg}$ & 207 & $10-y \Gamma$ DFS $^{1} 47.7 \%$ \\
\hline & & & & Pelvis $45 \mathrm{~Gy} / 25$ f or $50 \mathrm{~Gy} / 25$ f & & & $10-y г \cos ^{2} 58.1 \%$ \\
\hline & & & & Prostate $70 \mathrm{~Gy} / 35[$ & & & 10-yr PCM 10.3\% \\
\hline & & & & & Arm 2: None & 208 & 10-yr DFS ${ }^{1} 22.7 \%(p<0.0001)$ \\
\hline & & & & & & & $\begin{array}{l}10-y \operatorname{coS}^{2} 39.8 \%(p=0.0004) \\
10-y r \text { PCM 30.4\% }(p<0.0001)\end{array}$ \\
\hline \multirow{7}{*}{$\begin{array}{l}\text { Lawton et at. [20] } \\
\text { RTOG } 9202\end{array}$} & 3 & $\mathrm{NA}+\mathrm{CO}+\mathrm{AD}$ & $\mathrm{cT2c}-4+\mathrm{cNO}+\mathrm{iPSA}<150$ & EBRT & Arm 1: $\mathrm{N} \wedge$ goserelin $3.6 \mathrm{mg}+$ & 758 & $15-y r$ DFS ${ }^{1} 16 \%$ \\
\hline & & & & $\begin{array}{l}\text { Pelvis } 44 \mathrm{~Gy} / 24 \mathrm{f} \text { or } 46 \mathrm{~Gy} / 23 \mathrm{f} \\
\text { Prostate } 65 \mathrm{~Gy} / 36 \mathrm{f} \text { or } 70 \mathrm{~Gy} / 35 \mathrm{f}\end{array}$ & $\begin{array}{l}\text { futamide } 750 \mathrm{mg} / \mathrm{d}+\mathrm{AD} 2-\mathrm{yr} \\
\text { goserelin } 3.6 \mathrm{mg}\end{array}$ & & $\begin{array}{l}15-y r \cos ^{2} 21 \% \\
15-y r \operatorname{css}^{2} 84 \%\end{array}$ \\
\hline & & & & & & & $15-\mathrm{yr} \mathrm{DM}^{2} 17 \%$ \\
\hline & & & & & Arm 2: Nh goserelin $3.6 \mathrm{mg}+$ & 762 & 15 -yг DFS $110 \%(p<0.0001)$ \\
\hline & & & & & nutamide $750 \mathrm{mg} / \mathrm{d}+\mathrm{AD}$ None & & $15-\operatorname{yros}^{2} 17 \%(p=0.09)$ \\
\hline & & & & & & & $15-y \operatorname{CSS}^{2} 78 \%(p=0.002)$ \\
\hline & & & & & & & $15-\mathrm{yr} \mathrm{DM}{ }^{2} 26 \%(p<0.0001)$ \\
\hline \multirow{2}{*}{ Ito et al. [24] } & 3 & $\mathrm{AD}$ & $\mathrm{CT} 3-4, \mathrm{cNO}, \mathrm{CMO}$ & $\begin{array}{l}\text { CRT } \\
\text { Prostate } 72 \mathrm{Cy} / 36 \mathrm{f}+20 \mathrm{mo} \Lambda \mathrm{DT}\end{array}$ & $\begin{array}{l}\text { Arm 1: Continuous LHRHa until } \\
5 \mathrm{yr}\end{array}$ & 136 & 5-yr biochenical RFS ${ }^{2} 84.8 \%$ \\
\hline & & & & & Arm 2: Internittent LHRHa & 144 & 5-yr biochemical RFS ${ }^{3} 82.8 x(p=0.56)$ \\
\hline Nabid et al. [25] & 3 & $\mathrm{CO}-\mathrm{AD}$ & $\geq 1$ risk factor: $\mathrm{CT} 3-4, \mathrm{PSA}>20$ & EBRT & Arm 1: 3-yr goserelin $10.8 \mathrm{mg}$ & 310 & $10-y r \cos ^{1} 62.4 x$ \\
\hline $\begin{array}{l}\text { NCTO0223171 } \\
\text { PCSIV }\end{array}$ & & & $\mathrm{bGS}>7$, and $\mathrm{CNO}, \mathrm{CMO}$ & $\begin{array}{l}\text { Pelvis } 44 \mathrm{~Gy} / 22 \mathrm{f} \\
\text { Prostate } 70 \mathrm{~Gy} / 35 \mathrm{f}\end{array}$ & Arm 2: 1.5-yr goserelin $10.8 \mathrm{mg}$ & 320 & $10-y \cos ^{3} 62.0 \%(p=0.8412)$ \\
\hline James et al. [48] & 3 & $N A-C O-A D$ & CT3-4, bGS 8-10, iPS $\geq \geq 40$, and & 3D-CRT/IMRT & & & - \\
\hline \multirow[t]{2}{*}{ STAMPEDE } & & & $\mathrm{CNO}-1, \mathrm{cMO}$ & Prostate $74 \mathrm{~Gy} / 37 \mathrm{f} \perp$ Pelvis $46-50 \mathrm{~Gy} /$ & Arm 1: ADT & 396 & Reference \\
\hline & & & & $\begin{array}{l}37 \mathrm{f} \\
(55 \mathrm{~Gy} / 37 \mathrm{fIMRT} \text { ) } \\
\text { (obligatory only for } \mathrm{cNO} \text { ) }\end{array}$ & $\begin{array}{l}\text { Arm 2: ADT + abiraterone } \\
1000 \mathrm{mg} / \mathrm{d}+\text { prednisolone } 5 \mathrm{mg} / \mathrm{d}\end{array}$ & 396 & $\begin{array}{l}O^{1} \mathrm{HR} 0.64(0.38-1.08) \\
\text { FFS }^{3} \mathrm{HR} 0.18(0.12-0.28)\end{array}$ \\
\hline \multicolumn{8}{|l|}{ Chemohornonal } \\
\hline Chen et al. [32] & 1 & $\mathrm{CO}$ & CT3 or 4 or $b G S \geq 8$ or $\mathrm{PPSA} \geq 20$ & IMRT Prostate $78 \mathrm{~Gy} / 39 \mathrm{f}$ & LHRHa + docetaxel $10-20 \mathrm{mg} / \mathrm{m}^{2}$ & 18 & $\begin{array}{l}\text { MTD }{ }^{3} 20 \mathrm{mg} / \mathrm{m}^{2} / \mathrm{wk} \\
2-\mathrm{yr} \text { BRFS }{ }^{2} 94 \%\end{array}$ \\
\hline Marshall et al. [33] & 1 & co & $\begin{array}{l}\mathrm{cT} \geq 2 \mathrm{c} \text { and/or } \mathrm{bGS} \geq 8 \text { and } / \mathrm{or} \text { PSA } \\
\geq 20 \text { and } \mathrm{cMO}\end{array}$ & IMRT Prostate $77.4 \mathrm{~Gy} / 43 \mathrm{f}$ & $\begin{array}{l}\text { LHRHa + bicalutamide } 50 \mathrm{mg} / \mathrm{d}+ \\
\text { docetaxel } 10-30 \mathrm{mg} / \mathrm{m}^{2}+ \\
\text { dexamethasone } 10 \mathrm{mg}\end{array}$ & 19 & MID $25 \mathrm{mg} / \mathrm{m}^{2} / \mathrm{wk}$ \\
\hline \multirow[t]{2}{*}{$\begin{array}{l}\text { Sandler et al. [38] } \\
\text { RTOG 0521 }\end{array}$} & 3 & $A D$ & $\begin{array}{l}c T \geq 2+\text { bGS8 or bCS } 7-8+i P S A \\
20-150 \text { or bGS } 9-10+i P S A \leq 150\end{array}$ & $\begin{array}{l}\text { 3D-CRT/IMRT Prostate } 72.0 \mathrm{~Gy} / 40 \mathrm{f}- \\
75.6 \mathrm{~Gy} / 42 \mathrm{f}+\text { Pelvis } 46.8 \mathrm{~Gy}\end{array}$ & $\begin{array}{l}\text { Arm } 1: 6 \text { cycles, } 3 \text { weekly docetaxel } \\
75 \mathrm{mg} / \mathrm{m}^{2}+\text { prednisone } 10 \mathrm{mg} / \mathrm{d}+ \\
20 \text { - } \mathrm{mo} \mathrm{LHRHa}\end{array}$ & 282 & $\begin{array}{l}\text { 4-yr } \text { OS }^{3} 93 \% \\
5-y r \text { DFS }^{2} 73 \%\end{array}$ \\
\hline & & & & & Arm 2: 20-mo LHRHa & 281 & 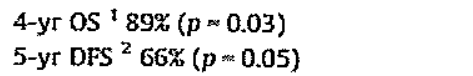 \\
\hline James et al. [12] & 3 & NA & CT3-4, DGS $8-10$, iPS $\Lambda \geq 40$, and & 3D-CRT/IMRT Prostate 74 Gy/37 f $\perp$ & & & \\
\hline \multirow[t]{5}{*}{ STAMPEDE } & & & $\mathrm{cNO}-1, \mathrm{cMO}$ & Pelvis $46-50 \mathrm{Cy} / 37 \mathrm{f}(55 \mathrm{Cy} / 37 \mathrm{f}$ IMRT) & Arm 1: ADT (control arm) & 460 & Reference \\
\hline & & & & (obligatory only for $\mathrm{CNO}$ since 2011) & $\begin{array}{l}\text { Am 2: ADT }+6 \text { cycles, } 3 \text { weekly } \\
\text { docet axel } 75 \mathrm{mg} / \mathrm{m}^{2}\end{array}$ & 230 & $\mathrm{OS}^{1} \mathrm{HR} 1.11(0.67-1.85)$ \\
\hline & & & & & Arm 3: ADT + 2-yr zoledronic acid & 227 & OS $^{1}$ HR $0.74(0.42-1.29)$ \\
\hline & & & & & $4 \mathrm{mg} \mathrm{3-4}$ weekly & & FFS ${ }^{3}$ HR $0.84(0.60-1.17)$ \\
\hline & & & & & $\begin{array}{l}\text { Arm 4: } A D T+6 \text { cycles, } 3 \text { weckly } \\
\text { docetaxel } 75 \mathrm{mg} / \mathrm{m}^{2}+\text { zoledronic } \\
\text { acid } 4 \mathrm{mg} 3-4 \text { weekly }\end{array}$ & 228 & $\begin{array}{l}\mathrm{OS}^{1} \text { HR } 0.79(0.45-1.40) \\
\text { FFS }{ }^{1} \text { HR } 0.69(0.48-0.99)\end{array}$ \\
\hline
\end{tabular}


Table 1 (Continued)

\begin{tabular}{|c|c|c|c|c|c|c|c|}
\hline Reference & Phase & $\mathrm{TT}$ & Risk factors & EBRT & Arms & SS & Endpoints \\
\hline $\begin{array}{l}\text { Rosenthal et al. [A3] } \\
\text { RTOG } 9902\end{array}$ & 3 & $\mathrm{AD}$ & $\begin{array}{l}\text { any } \mathrm{cT}+\mathrm{iPSA} 20-100 \mathrm{ng} / \mathrm{ml}+\mathrm{bGS} \\
\geq \text { or } \mathrm{CT} \geq 2+\mathrm{bGS} 8-10+\mathrm{iPSA} \leq 100 \\
\mathrm{ng} / \mathrm{ml} \text { and NO, M0 }\end{array}$ & $\begin{array}{l}\text { EBRT } \\
\text { Pelvis } 46.8 \mathrm{~Gy} / 26 \mathrm{f} \\
\text { Prostate } 70.2 \mathrm{~Gy} / 39 \mathrm{f}\end{array}$ & $\begin{array}{l}\text { Arm 1: 2-yг ADT + estramustine } \\
280 \mathrm{mg} \text { ПD + etoposide } 50 \mathrm{mg} / \mathrm{m}^{2} \\
\text { BID + pactitaxel } 135 \mathrm{mg} / \mathrm{m}^{2} \\
\text { Arm 2: 2-yг ADT }\end{array}$ & $\begin{array}{l}200 \\
197\end{array}$ & 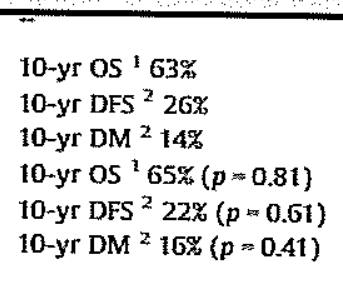 \\
\hline Corn et al. $[53]$ & 1 & $\mathrm{NA}+\mathrm{CO} \div \mathrm{AD}$ & $\begin{array}{l}\text { CT2C- }-4 \text { and } / 0 \text { bGS } 8-10 \text { and } / \text { or } \\
\text { iPSA }>20 \text { and } c M 0\end{array}$ & IMRT Prostate $75.6 \mathrm{~Gy} / 42 \mathrm{f}$ & $\begin{array}{l}\text { Sunitinib } 12.5-25-37.5 \mathrm{mg}+2-\mathrm{yr} \\
\text { leuprolide } 22.5 \mathrm{mg} \text { or goserelin } \\
\text { to.8 } \mathrm{mg}\end{array}$ & 17 & $\begin{array}{l}\mathrm{RP} 2 \mathrm{D}^{2} 25 \mathrm{mg} / \mathrm{d} \\
\mathrm{DLT}^{2} 37.5 \mathrm{mg} / \mathrm{d}\end{array}$ \\
\hline Azria et al. $[54]$ & 1 & $\mathrm{CO}$ & $\begin{array}{l}\mathrm{CT} \geq 3 \text { or } \mathrm{bGS} \geq 8 \text { or iPSA } \geq 20 \text { and } \\
\mathrm{cMO}\end{array}$ & EBRT Prostate 74 Gy/37 f & $\begin{array}{l}\text { Everolinus } 5-7.5-10 \mathrm{mg} / \mathrm{d}+ \\
\text { leuprolide }+ \text { bicalutanide }\end{array}$ & 15 & MTD $17.5 \mathrm{mg} / \mathrm{d}$ \\
\hline Carles et al. [55] & 2 & $\mathrm{NA}+\mathrm{CO}+\mathrm{AD}$ & $\begin{array}{l}\text { cT3a } M 0+\text { bGS }>7 \text { or } \text { IPSA }>20 \text { or } \\
\text { CT4MO or } \mathrm{CN1}\end{array}$ & $\begin{array}{l}\text { 3D-CRT } \\
\text { Pelvis } 45 \text { Gy/25 for } 46 \text { Gy/23 f } \\
\text { Prostate } 70.2 \text { Gy/39 for } 70 \text { Gy/35 f }\end{array}$ & $\begin{array}{l}\text { Estramustine } 600 \mathrm{mg} / \mathrm{m}^{2} / \mathrm{d}+ \\
3 \text { cycles vinorelbine } 25 \mathrm{mg} / \mathrm{m}^{2}+3- \\
\text { yr LHRHa }\end{array}$ & so & 5 -yr $\operatorname{PFS}^{1} 72 x$ \\
\hline Bolla et al. $[34]$ & 2 & $\mathrm{CO}+\mathrm{AD}$ & $\begin{array}{l}\text { cT1-2 + bGS } 8-10 \text { or iPSA }>20 \text { or } \\
\text { cT3-4, N0, M0 or CN1/pN1. MO } \\
\text { At least } 2 \text { risk factors: } \mathrm{CT3}-4, \text { bGS }\end{array}$ & $\begin{array}{l}\text { 3D-CRT/IMRT } \\
\text { Pelvis } 46 \text { Gy/23 f } \\
\text { Prostate } 70 \text { Gy/35 r } \\
\text { 3D-CRT/IMRT }\end{array}$ & $\begin{array}{l}\text { 3-yr LHRHa }+6 \text { cycles, } 3 \text { weekly } \\
\text { docetaxel } 20 \mathrm{mg} / \mathrm{m}^{2} / \mathrm{wk}\end{array}$ & 50 & $\begin{array}{l}\text { Grade } 3-4 \text { toxicity }<5 z^{2} \\
5-y r \text { DFS } 266.72 \% \\
5-y \operatorname{OS}^{2} 92.15 x\end{array}$ \\
\hline STAMPEDE & & & $8-10$, iPS $\geq 40, \mathrm{cNO}-1, \mathrm{cMO}$ & $\begin{array}{l}\text { Prostate } 74 \mathrm{Cy} / 37 \mathrm{f} \perp \text { Pelvis } \\
46-50 \mathrm{~Gy} / 37 \mathrm{f}(55 \mathrm{~Gy} / 37 \mathrm{f} \mathrm{MRT}) \\
\text { (obligatory only for cNO since } 2011)\end{array}$ & $\begin{array}{l}\text { Arm 1: ADT } \\
\text { Arm 2: } A D T+\text { celecoxib } 800 \mathrm{mg} / \mathrm{d} \\
\text { Arm 3: ADT + celecoxib } 800 \mathrm{mg} / \mathrm{d}+ \\
\text { 2-yr zoledronic acid } 4 \mathrm{mg} / 15 \mathrm{~min}\end{array}$ & $\begin{array}{l}245 \\
124 \\
121\end{array}$ & $\begin{array}{l}\text { Reference } \\
\text { OS }^{1} \mathrm{HR} 1.06(0.59-1.91) \\
\text { OS }^{1} \mathrm{HR} 0.94(0.52-1.70)\end{array}$ \\
\hline $\begin{array}{l}\text { a agonist A - active } \\
\text { survival, DFS = diseas } \\
\text { intensity modulated r } \\
\text { mortality. PFS - progr } \\
\text { dimensional conform } \\
\text { Primary endpoint. } \\
\text { secondary endpoint } \\
\text { HR with combination } \\
\text { Accrual suspended }\end{array}$ & diation & $\begin{array}{l}\text { survival; PSA p } \\
\text { herapy. } \\
\text { the EBRT subgro } \\
\text { thromboembolis }\end{array}$ & 4 & 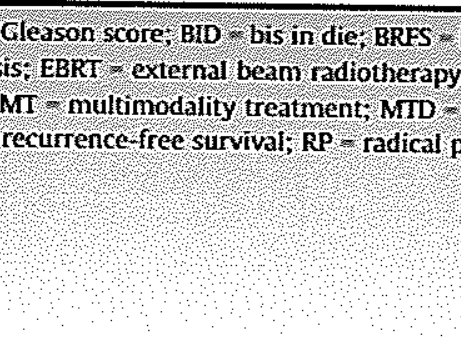 & ectony, ss - sample size; no r ter & & 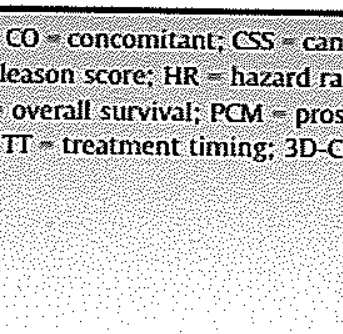 \\
\hline
\end{tabular}




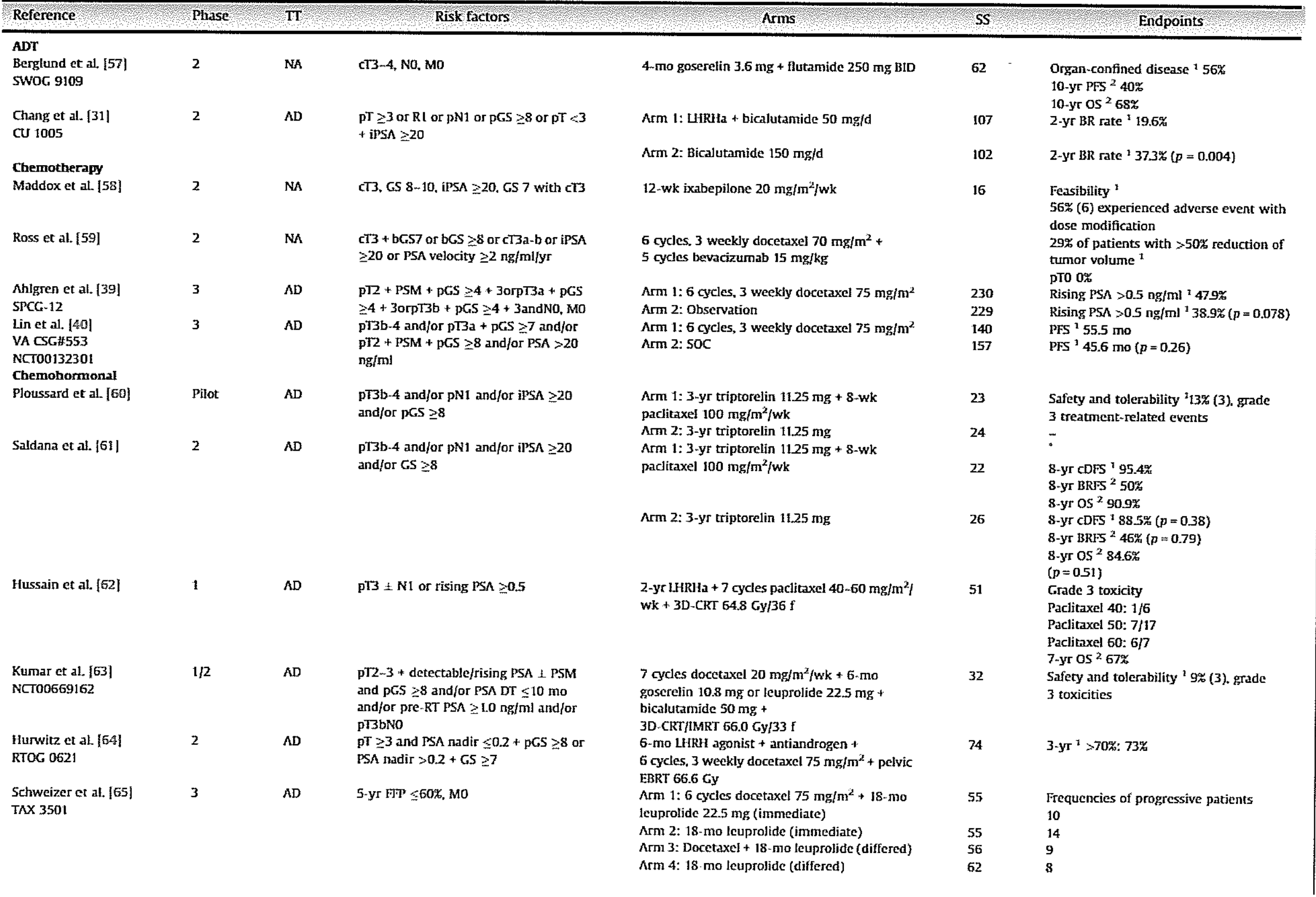


Table 2 (Continued)

\begin{tabular}{|c|c|c|c|c|c|c|}
\hline Reference & Phase & TI & Risk factors & Arms & SS & Endpoints \\
\hline Zurita et al [66] & 2 & $\mathrm{NK}$ & $\begin{array}{l}\mathrm{CT} 3+\mathrm{CS} \geq 7 \text { or } \mathrm{CT} 4 \text { and/or } \mathrm{CN} 1, \mathrm{CMO} \text { and } \\
\mathrm{bGS} \geq 8+\mathrm{PPSA} \geq 25\end{array}$ & $\begin{array}{l}\text { 1-yr LHRHa } \leq \text { bjcalutamide } 50 \mathrm{mg} / \mathrm{d}+ \\
\text { docetaxel } 35 \mathrm{mg} / \mathrm{m}^{2} \\
\text { (days } 1,8.15 \text { and } 22 \text { every } 6 \text { wk) }\end{array}$ & 39 & $\begin{array}{l}\text { 1-yr PSA recurrence } 50 \%(10 / 20) \\
\text { pTo } 8 \%(2 / 26)\end{array}$ \\
\hline Thatgott et at. $|67|$ & 2 & $\mathrm{NA}$ & $\begin{array}{l}\text { M0 And risk of 5-yr biochemical } \\
\text { recurrence }>40 \% \text { (Kattan nomogram) }\end{array}$ & $\begin{array}{l}\text { Buserelin } 9.45 \mathrm{mg}+\text { bicalutamide } 50 \mathrm{mg} / \mathrm{d}+ \\
3 \text { cycles docetaxel } 75 \mathrm{mg} / \mathrm{m}^{2}\end{array}$ & 30 & $\begin{array}{l}\text { 13.3\% complete PSA response }{ }^{1} \\
48 \% \text { T downstaging }{ }^{1} \\
0 \% \text { pro }\end{array}$ \\
\hline Narita et al_[68] & Pilot & $\mathrm{NA}$ & $c T \geq 3$ and/or iPSA $\geq 15$ and/or $G S \geq 9$ & $\begin{array}{l}\text { 1-yr leuprorelin } 11.25 \mathrm{mg}+\text { bicalutamide } \\
81 \mathrm{mg}+ \\
6 \text { cycles docetaxel } 30 \mathrm{mg} / \mathrm{m}^{2}+\text { estramustine } \\
560 \mathrm{mg}\end{array}$ & 18 & pro ${ }^{1} 11.1 \%$ \\
\hline Koie et al. [69] & 2 & NA & $\mathrm{cT} 2 \mathrm{c}-3$ and/or iPS $\Lambda \geq 20$ and/or $\mathrm{GS} \geq 8$ & $\begin{array}{l}\text { 3-mo leuprolide } 11.25 \mathrm{mg} \text { or goserelin } 10.8 \mathrm{mg} \\
\text { + } 6 \text {-mo estramustine } 280 \mathrm{mg}\end{array}$ & 142 & $\mathrm{pro}^{1} 4.9 \%$ \\
\hline Silberstein et al. $[70]$ & 2 & $\mathrm{NA}$ & $\begin{array}{l}\mathrm{CT} \geq 3 \text { and } \mathrm{or} \text { iPS } \Lambda>20 \text { andjor } \\
\mathrm{bGS} \geq 8\end{array}$ & $\begin{array}{l}\text { Coserelin } 10.8 \mathrm{mg}+\text { paditaxel } 60-100 \mathrm{mg} / \mathrm{m}^{2} / \\
\text { wk + carboplatin } 6 \mathrm{mg} / \mathrm{ml} \text {-min } / 4 \mathrm{wk}+3 \mathrm{cycles} \\
\text { estramustine } 10 \mathrm{mg} / \mathrm{kg} / \mathrm{d}\end{array}$ & 34 & $\begin{array}{l}10-\mathrm{yr} \cos ^{1} 78 \% \\
10-\mathrm{yr} \operatorname{css}^{3} 84 \% \\
\text { pTo ox }\end{array}$ \\
\hline Nosov et al. [51] & 3 & $\mathrm{NA}$ & $\begin{array}{l}\mathrm{cr} \geq 2 \mathrm{c} \text { and/or } \mathrm{bGS} \geq \mathrm{B} \text { and/or } \mathrm{iPS} A>20 \\
\mathrm{ng} / \mathrm{ml} \text { and/or } \mathrm{N} 1\end{array}$ & $\begin{array}{l}\text { Arm i: } 6 \text { cycles, } 3 \text { weekly docetaxel } 75 \mathrm{mg} / \mathrm{m}^{2} \\
\text { t monthly degarelix } 240 / 80 \mathrm{mg}\end{array}$ & 19 & I-yr RFS $16.7 \%$ \\
\hline \multicolumn{7}{|c|}{ Arm 2: Monthly degarelix $240 / 80 \mathrm{mg}$} \\
\hline Dean et al. [71] & 2 & N & $\begin{array}{l}\text { CT2c- } 3 \text { and/or } b G S \geq 8 \text { and/or iPSA } \geq 20 \\
\text { or a risk of relapse }>50 \%\end{array}$ & $\begin{array}{l}\text { Coserelin + bicalutamide + 3-mo cixutumumab } \\
\text { (IMC-A12) } 10 \mathrm{mg} / \mathrm{kg} / 2 \mathrm{wk}\end{array}$ & 28 & pTo $^{1}$ (not available) \\
\hline Vuky et al. [72] & 2 & NA & High risk prostate cancer & $\begin{array}{l}4 \text { cycles, } 3 \text { weekly docetaxel } 75 \mathrm{mg} / \mathrm{m}^{2}+ \\
4 \text { cycles GVAX }\end{array}$ & 6 & Terminated for safety concerns $0 \%$ pTo \\
\hline Ross et al. $[73]$ & 1 & $\mathrm{~N}$ & $\mathrm{cr} \geq 3$ and $/$ or $\mathrm{bGS} \geq 8$ and/or $\mathrm{PSA} \geq 20$ & $\begin{array}{l}\text { Arm 1: 4.wk sonidegib } 800 \mathrm{mg} / \mathrm{d} \\
\mathrm{Arm} 2: \text { None }\end{array}$ & $\begin{array}{l}7 \\
7\end{array}$ & $\begin{array}{l}\text { 36\% Two-fold reduction of Gl.11 mRNA } \\
0 \%\end{array}$ \\
\hline 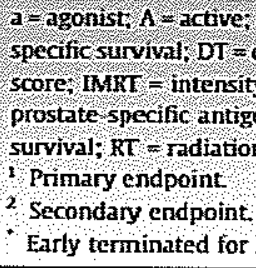 & ros & 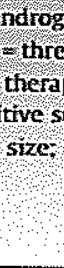 & largins, R= recruitings $S$ - suspend & topped & & 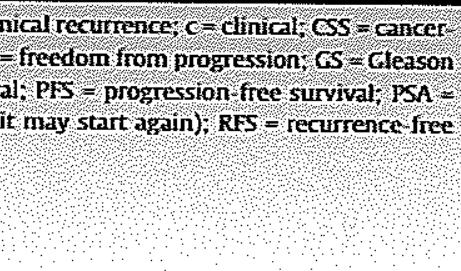 \\
\hline
\end{tabular}


Table 3 - Summary of the results of clinical trials using systemic treatments together with either EBRT or radical prostatectomy as local treatments

\begin{tabular}{|c|c|c|c|c|c|c|}
\hline Reference & Phase & $T^{2}$ & Risk factors & Arms & SS & Endpoints \\
\hline \multicolumn{7}{|c|}{ Chemohormonal therapy } \\
\hline \multirow[t]{2}{*}{ Guttilla et al. (74) } & 2 & $A D$ & $\begin{array}{l}\text { cT2c-3 or iPSA } \geq 20 \text { or } \\
\text { bGS } \geq 8 \text { or } N 1\end{array}$ & $\begin{array}{l}\text { Arm 1: RP + ePLND AD IMRT prostate } \\
70 \mathrm{~Gy} / 35 \mathrm{f}+7 / 8 \text { wk docetaxel } 30-40 \\
\mathrm{mg} / \mathrm{m}^{2} / \mathrm{wk}+2 \text {-yr LHRHa }\end{array}$ & 18 & $\begin{array}{l}\text { Safety and tolerability }{ }^{1} \text { : } \\
\text { Arm 1: } 9 \% \text { gastrointestinal grade } 3 \text {. }\end{array}$ \\
\hline & & $\mathrm{CO}$ & & $\begin{array}{l}\text { Arm 2: IMRT prostate/pelvis } 80 \mathrm{~Gy}+2 \text {. } \\
\text { ys LHRHa }\end{array}$ & 17 & $\begin{array}{l}\text { Arm 2: 6\% gastrointestinal grade } 3 \text {, } \\
6 \% \text { genitourinary grade } 3 .\end{array}$ \\
\hline \multirow[t]{2}{*}{$\begin{array}{l}\text { Fizazi et al. } \mid 36\rceil \\
\text { GETUG } 12\end{array}$} & 3 & $N A$ & $\begin{array}{l}\text { CT3 }-4 \text { and/or bGS } \geq 8 \\
\text { and/or ijs } A>20 \text { and/or } \\
\text { pNI and Mo }\end{array}$ & $\begin{array}{l}\text { Arm } 1: 4 \text { cycles docetaxel } 70 \mathrm{mg} / \mathrm{m}^{2} / 3 \\
\text { wk }+5 \mathrm{~d} \text { every } 3 \text { wk estramustine } \\
10 \mathrm{mg} / \mathrm{kg} / \mathrm{d}+3-\mathrm{yr} \text { goserelin } 10.8 \mathrm{mg}+ \\
\text { 3D-CRT } 74-78 \mathrm{~Gy} / 37-39 \mathrm{f} \text { prostate } \perp \\
\text { pelvis } \text { PLND or RP }\end{array}$ & 207 & $\begin{array}{l}\text { Safety and tolerability }{ }^{3} 48 \% \text { grade } \\
3-4 \text { events }\end{array}$ \\
\hline & & & & $\begin{array}{l}\text { Arm 2: 3-yr goserelin } 10.8 \mathrm{mg}+3 \mathrm{D} \\
\text { CRT } 74 \text { Gy/41 f-78 Gy/39 f prostate } 1 \\
\text { pelvis + PLND or Rp }\end{array}$ & 206 & oo grade 3-4 events \\
\hline \multirow[t]{2}{*}{$\begin{array}{l}\text { Fizazi et al. }[37] \\
\text { GETUG-12 }\end{array}$} & 3 & NA & $\begin{array}{l}\text { cT3 }-4 \text { and/or bCS } \geq 8 \\
\text { and/or iPSA }>20 \text { and/or } \\
\text { N1 }\end{array}$ & $\begin{array}{l}\text { Arm } 1: 4 \text { cycles docetaxel } 70 \mathrm{mg} / \mathrm{m}^{2} / 3 \\
\text { wk }+5 \mathrm{~d} \text { every } 3 \text { wk estramustine } \\
10 \mathrm{mg} / \mathrm{kg} / \mathrm{d}+3 \text {-yr goserelin } 10.8 \mathrm{mg} * \\
30-C R T 74-78 \mathrm{~Gy} / 37-39 \mathrm{f} \text { prostate } \pm \\
\text { pelvis }+ \text { PLND or } \mathrm{RP}\end{array}$ & 207 & 8-yr RFS 62\% \\
\hline & & & & $\begin{array}{l}\text { Arm 2: 3-yr goserelin } 10.8 \mathrm{mg} \text { + 3D } \\
\text { CRT 74 Gy/41 f-78 Gy/39 f prostate } \\
\text { pelvis * PLND or RP }\end{array}$ & 206 & 8-yr RFS $50 \%(p=0.017)$ \\
\hline \multicolumn{7}{|l|}{ Others } \\
\hline Valicentî et al. $[75]$ & 1 & NA & $\begin{array}{l}C T \geq 2+\text { bGS } \geq 8+i P S A \\
\leq 150 \text { or iPSA }>20-150 \\
\text { and bGS } \geq 7 \text { or and/or } \\
\text { pN1 and } M 0\end{array}$ & $\begin{array}{l}\text { I cycle samarium } 153 \text { lexidronam } \\
(0.25-2.0 \mathrm{mCl} / \mathrm{kg})+\text { leuprolide or } \\
\text { goserelin + flutamide } 250 \mathrm{mg} / \mathrm{d} \text { or } \\
\text { bicalutamide } 50 \mathrm{mg} / \mathrm{d} \text { + prostate } / \text { pelvic } \\
\text { EBRT } 70.2 \mathrm{~Gy} / 39 \mathrm{f}\end{array}$ & 29 & $\begin{array}{l}\text { MTD } \\
2.0 \mathrm{mCi} / \mathrm{kg}^{153} \mathrm{sm}-\mathrm{EDTMP}\end{array}$ \\
\hline NCT00294437 & 3 & $\mathrm{AD}$ & CT3 -4 and IPSA $>20$ & Arm l: Zoledronic acid $4 \mathrm{mg} / 100 \mathrm{ml}$ & & s \\
\hline CECOG/prostate 12.001 & & & $\mathrm{ng} / \mathrm{ml}$ and bGSs & Arm 2: None & 376 & Time to first bone metastasis ${ }^{1}$ \\
\hline
\end{tabular}

$\mathrm{a}=$ agonist, $\mathrm{A}=$ active; $\mathrm{AD}=\mathrm{adjuvant}$ bGS - biopsy Gleason score; $\mathrm{C}=$ dincal, $C O=$ concomitant, $3 \mathrm{D}$ CRT $=$ three dimensional conformal radiation therapy: EBRT = external beam radiotherapy; (e)pLND = (extended) pelvic lymphadenectomy; $f=$ fractions; GS = Gleason score; IMRT = intensity modulated radiation therapy, LHRH = luteinizing hormone-releasing hormone; $\mathrm{MT}$ = multimodality treatrnent MTD = maximal tolerated dose; NA = neoadjuvant; PSA = prostate. specific antigen ( $\mathrm{ng} / \mathrm{ml}$ ); RFS - recurrence free survival; RP - radical prostatectomy, SS - sample size; TT - treatment tining

1 Primary endpoint

Terminated for underfunding- 
Table 4 - Summary of the ongoing trial setting using systemic treatments together with EBRT as local treatment

\begin{tabular}{|c|c|c|c|c|c|c|c|c|c|}
\hline Reference & Phase & $\mathrm{TT}$ & Risk lactors & EBRT & Arrns & I endpoint & Status & SS & $\begin{array}{l}\text { Estimated } \\
\text { completion date }\end{array}$ \\
\hline \multicolumn{10}{|c|}{$T Z$ Or jaxa $>0$ ar $C S$ SROT } \\
\hline $\begin{array}{l}\text { NCTO } 1439542 \\
\text { FASTR }\end{array}$ & 2 & $C O A D$ & $\begin{array}{l}\mathrm{CT} 3 \text { or } \mathrm{PSSA} \geq 20 \text { or } \mathrm{GS} \\
\geq 8\end{array}$ & $\begin{array}{l}\text { SBRT } \\
25 \text { Gy/5f Pelvis } \\
40 \text { Gy/5f Prostate }\end{array}$ & 1-yt LFRHa & Safety and tolerability & $\mathrm{TE}$ & & $\begin{array}{l}\text { Accrual goal not reached } \\
\text { due to excess of toxicity }\end{array}$ \\
\hline $\begin{array}{l}\text { NCT02229734 } \\
\text { FASTR-2 }\end{array}$ & 2 & $C O \cdot A D$ & $\begin{array}{l}\text { Iligh-risk prostate } \\
\text { cancer }\end{array}$ & $\begin{array}{l}\text { SBRT } \\
35 \text { Gyl Prostate }\end{array}$ & 1.5-yr leuprolide $45 \mathrm{mg}$ & $\begin{array}{l}\text { Safety } \\
\text { and tolerability }\end{array}$ & $\mathrm{R}$ & 60 & November 2019 \\
\hline NCT02772588 & 2 & NA.COAD & $\begin{array}{l}\mathrm{CT} \geq 3 \text { and } / \mathrm{or} \text { iPSA } \geq 20 \\
\text { and/or GS } \geq 8\end{array}$ & $\begin{array}{l}\text { Ultrafractionated } \\
\text { (SBRT) }\end{array}$ & $\begin{array}{l}\text { 6-mo apalutamide }(A R N-509)+ \\
\text { abiraterone } 1000 \mathrm{mg} / \mathrm{d} \text { * } \\
\text { leuprolide }\end{array}$ & Biochemical failure & $\mathbf{R}$ & 58 & May 2019 \\
\hline NCT02064582 & 2 & $\mathrm{NA}-\mathrm{CO}-\mathrm{AD}$ & $\begin{array}{l}\text { High-risk prostate } \\
\text { cancer }\end{array}$ & EBRT & $\begin{array}{l}\text { Leuprolide } 22.5 \mathrm{mg} / 45 \mathrm{mg}+6 \\
\text { mo enzalutamide } 160 \mathrm{mg} / \mathrm{d}\end{array}$ & Safety and tolerability & $\mathrm{R}$ & 15 & April 2019 \\
\hline NCT02508636 & 2 & $C O \cdot A D$ & $\begin{array}{l}\geq 2 \text { risk factors: } \\
\text { CT3a3b } \\
\text { IPSA } \geq 20 \\
\text { bGS } 8-10 \\
>33 \% \text { cores } \\
\text { CN1 }\end{array}$ & EBRT & $\begin{array}{l}\text { 2-yr leuprolide } 225 \mathrm{mg} / 45 \mathrm{mg}+ \\
\text { enzalutamide } 160 \mathrm{mg} / \mathrm{d}\end{array}$ & Safety and tolerability & $\mathbf{R}$ & 53 & June 2022 \\
\hline $\begin{array}{l}\text { NCT02446444 } \\
\text { ENZARAD }\end{array}$ & 3 & $N A-C O-A D$ & $\begin{array}{l}\text { cT2-4 and bCS } 4+ \\
3 \text { and iPSA }>20 \text { or GS } \\
8-10 \text { or } N 1\end{array}$ & $\begin{array}{l}\text { EBRT } 78 \text { Gy/39 f or } \\
46 \text { Gy/23f }+ \\
\text { brechytherapy boost }\end{array}$ & $\begin{array}{l}\text { Arm 1:2-yr enzalutamide } 160 \mathrm{mg} / \\
\mathrm{d}+1 \mathrm{HRH} \text { la } \\
\text { Arm 2: 2-yr antiandrogen + LHRHa }\end{array}$ & 05 & $\mathbf{R}$ & 800 & December 2021 \\
\hline $\begin{array}{l}\text { NCT01546987 } \\
\text { RTOG } 1115\end{array}$ & 3 & $N A-C O A D$ & $\begin{array}{l}C T \geq 2, \text { bCS } \geq 8, \text { JPSA } \\
\angle 20 \text { or } b G S \geq 9 \text {. iPSA } \\
\leq 150 \text { or bGS } \geq 8 \text {, iPSA } \\
\geq 20-150 \text { or bGS } \geq 7 \\
\text { iPSA } \geq 20-150\end{array}$ & Dose escalated EBRT & $\begin{array}{l}\text { Arm 1: 2-yr UHRHa + } \\
\text { antiandrogen } \\
\text { Arm 2: 2-yr LHRHa + antiadrogen } \\
+ \text { TAK700 }\end{array}$ & os & 0 & 239 & June 2020 \\
\hline $\begin{array}{l}\text { NCT02531516 } \\
\text { ATUS }\end{array}$ & 3 & NA-CO-AD & $\begin{array}{l}C T \geq 2 C, G S \geq 8 \text { or } G S \geq 7, \\
\text { iPSA } \geq 20, c T 2 c\end{array}$ & EBRT 74-80 Gy & $\begin{array}{l}\text { Arm 1: } 2.5 \text {-yr LHRHa + placebo } \\
\text { bicalutamide + apalutamide } \\
240 \mathrm{mg} / \mathrm{d} \\
\text { Arm 2: } 2.5 \text {-yr L.HRH agonist + } \\
\text { bicalutamide } 50 \mathrm{mg}+\text { placebo } \\
\text { apalutamide }\end{array}$ & MFS & $\mathrm{R}$ & 1500 & October 2026 \\
\hline $\begin{array}{l}\text { NCT02799706 } \\
\text { EORTC } 1414 \\
\text { PEGASUS }\end{array}$ & 3 & $\mathrm{CO}-\mathrm{AD}$ & $\begin{array}{l}2 \text { risk factors: } \\
C T 3-4 \\
C N 1 \\
\text { bGS } \geq 8 \\
\text { PSA } \geq 20 \mathrm{ng} / \mathrm{ml}\end{array}$ & IMRT 78-80 Gy & $\begin{array}{l}\text { Arm 1: 15-3-yr degarelix } \\
\text { Arm 2: 1.5-3-yr LiRHa }\end{array}$ & PFS & not $\mathbf{R}$ & 885 & June 2024 \\
\hline \multicolumn{10}{|c|}{ Chemohormonal therapy } \\
\hline NCT03066154 & 1 & co & $\begin{array}{l}\mathrm{cN} 1+\mathrm{ct} \geq 2 \mathrm{c} \\
\mathrm{bGS} \geq 4+3\end{array}$ & IMRT $77 \mathrm{~Gy} / 35 \mathrm{f}$ & $\begin{array}{l}\text { Oral docetaxel (ModraDoco06) } \\
\text { ritonavir) + ADT }\end{array}$ & MTD & $\mathbf{R}$ & 24 & January 2020 \\
\hline NCT01420250 & 1 & co & $\begin{array}{l}b G S \geq 8 \\
b G S 7 \text { and } c \mathrm{~T} 3-4 \\
\text { bGS7 but IPSA } \geq 20 \text { and } \\
\text { Mo }\end{array}$ & IMRT $75.6 \mathrm{Cy} / 42 \mathrm{f}$ & $\begin{array}{l}\text { l.HRHa + bicalutamide }+ \\
\text { cabazitaxel } \\
4-10 \mathrm{~m}^{2}\end{array}$ & MTD & 0 & 20 & Septernber 2018 \\
\hline
\end{tabular}


Table 4 (Continued)

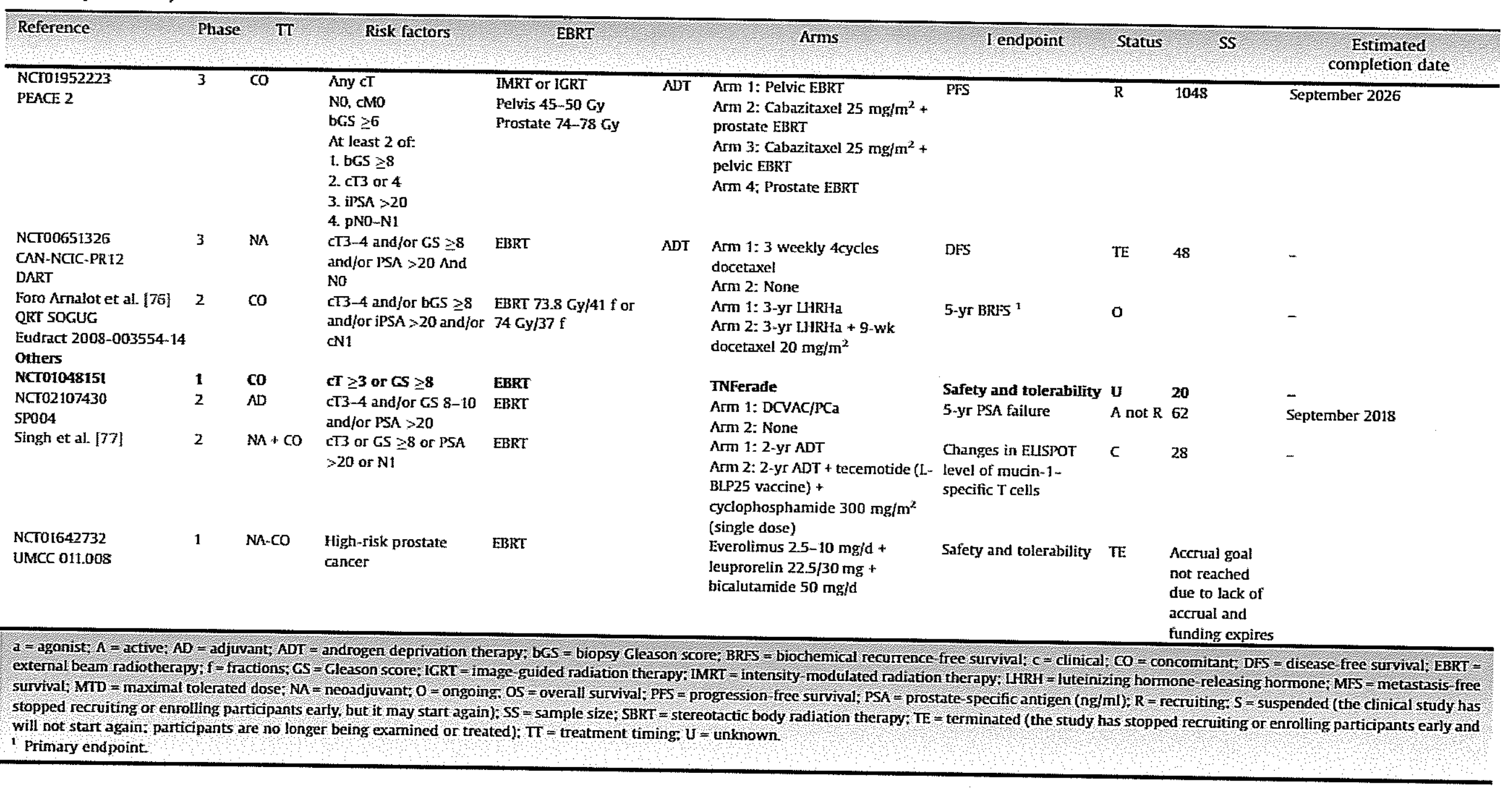


Table 5 - Summary of the ongoing trial setting wsing systemic treatments together with radical prostatectomy as Iocal treatment

\begin{tabular}{|c|c|c|c|c|c|c|c|c|c|}
\hline Reference & Phase & $T$ & Risk factors & EBRT & Arms & Tendpoint & Status & SS & $\begin{array}{l}\text { Estimated } \\
\text { completion date }\end{array}$ \\
\hline \multicolumn{10}{|c|}{$c B$ and/or $b G S \geq 8$ and/or iPSA $\geq 20 \mathrm{ng}$} \\
\hline NCT02789878 & 2 & $\mathrm{NA}$ & $\begin{array}{l}\mathrm{CTB} \text { and/or } \mathrm{bGS} \geq 8 \text { and } / \text { or } \mathrm{iPSA} \geq 20 \mathrm{ng} / \\
\mathrm{ml}\end{array}$ & - & $\begin{array}{l}\text { Arm 1: 3-mo goserelin } 10.8 \mathrm{mg} * \\
\text { abiraterone } 1000 \mathrm{mg} / \mathrm{d} \text { * prednisone } \\
5 \mathrm{mg} / \mathrm{d}+3 \text {-mo apalutamide (ARN-509) } \\
240 \mathrm{mg} / \mathrm{d} \\
\text { Arm 2: 3-mo goserelin } 10.8 \mathrm{mg} \text { * } \\
\text { abiraterone } 1000 \mathrm{mg} / \mathrm{d}+\text { prednisone } \\
5 \mathrm{mg} / \mathrm{d}\end{array}$ & рто & Not $R$ & 64 & October 2019 \\
\hline NCT02949284 & 2 & $\mathrm{NA}$ & $\begin{array}{l}\mathrm{bGS} \geq 8 \text { or iPSA } \geq 20 \mathrm{ng} / \mathrm{ml} * \text { no. of } \\
\text { positive biopsy cores }>1 \text { and resectable } \\
\text { prostate cancer } \mathrm{CTl}-3\end{array}$ & - & $\begin{array}{l}\text { Arm 1: 3-mo apalutamide (ARN-509) } \\
240 \mathrm{mg} / \mathrm{d} \text { t abiraterone } 1000 \mathrm{mg} / \mathrm{d}+ \\
\text { predrisone } \\
\text { Arm 2: 3-mo apalutamide (ARN-509) } \\
240 \mathrm{mg} / \mathrm{d} \\
\text { Arm 3: None }\end{array}$ & $\begin{array}{l}\text { Postoperative } \\
\text { potency rate }\end{array}$ & Not $\mathrm{R}$ & 90 & December 2018 \\
\hline NCT01255891 & 2 & $\mathrm{AD}$ & $\begin{array}{l}\text { pTSNO/NX } \perp \text { PSM and/or PGS } \geq 8 \text { and } / \\
\text { or PPSA }>20\end{array}$ & ERRT & LHRHa & 5-yr BRFS and CRFS & $\mathrm{U}$ & 46 & - \\
\hline $\begin{array}{l}\text { NCT01753297 } \\
\text { PRIORTI }\end{array}$ & 4 & $\mathrm{AD}$ & $\begin{array}{l}\text { pT3a and post-RP PSA } \leq 0.2 \text { and/or } \mathrm{PSS} A \\
\geq 20 \text { and/or } \mathrm{pGS} \geq 8, \text {, pN0. MO }\end{array}$ & - & $\begin{array}{l}\text { Arm 1: 9-mo triptorelin } 1125 \mathrm{mg} \\
\text { Arm 2: None }\end{array}$ & 5. -yT BRFS & 0 & 226 & June 2019 \\
\hline $\begin{array}{l}\text { Rozet et al. [79] } \\
\text { NCT01442246 } \\
\text { ARU/GETUC 20/0310 }\end{array}$ & 3 & $\mathrm{AD}$ & $\begin{array}{l}\text { PGS }>7 \\
\text { or pGS } \geq 7+G 5 \text { pattern } 5 \text { or prsb and } \\
\text { pNO, MO }\end{array}$ & - & $\begin{array}{l}\text { Am 1: 2-yr leuprolide } 45 \mathrm{mg} \\
\text { Arm 2: None }\end{array}$ & 10-yr MFS & $\mathbf{R}$ & 700 & January 2023 \\
\hline $\begin{array}{l}\text { Ornstein et al. [79] } \\
\text { NCTO1927627 } \\
\text { CASE12812 } \\
\text { Chemotherapy }\end{array}$ & 2 & $\mathrm{AD}$ & $\begin{array}{l}\text { वT } \geq 3 \text { andjor iPSA }>20 \text { and/or bCS }>8 \\
\text { and/or pN1 with postop PSA }<0.4 \text { or } \\
\text { risk of } B R \geq 35 \% \text { at } 5 \text { yr }\end{array}$ & - & Enzalutamide $160 \mathrm{mg}(40 \mathrm{mg} 4 \mathrm{co} / \mathrm{d}$ ) & $\begin{array}{l}\text { Time to } \\
\text { progression }\end{array}$ & 0 & 42 & March 2019 \\
\hline $\begin{array}{l}\text { NCTO1941550 } \\
\text { CIUBNET }\end{array}$ & 2 & NA & 5-yr relapse probability $\geq 60 \%$ & - & 6 cycles cabazitaxel $1 \mathrm{mg} / \mathrm{m}^{2}$ & pro & $T E$ & 11 & - \\
\hline $\begin{array}{l}\text { NCTO1650285 } \\
\text { BruOG } 246\end{array}$ & 2 & $A D$ & $\begin{array}{l}\text { pT3-4 and/or PSM and/or pT3b and/or } \\
\text { pNI and/or postop PSA }>1-<20+ \\
\text { pTZ-3 }\end{array}$ & IMRT $64.8 \mathrm{~Gy}$ & 3 doses cobazitaxel $5-20 \mathrm{mg} / \mathrm{m}^{2}$ & MTD & TE & 5 & - \\
\hline NCT01079793 & $1 / 2$ & $A \mathrm{D}$ & $\begin{array}{l}\text { pT3 or PSM } \\
\text { pNO, MO } \\
\text { pGS }=7 \text { with postop PSA }>0 \text { but } \leq 2 \text { or } \\
G S \geq 8 \text { and postop PSA } 0-2\end{array}$ & IMRT adj & 3 courses ixabepilone (dose escalation) & $\begin{array}{l}\text { Phase } 1 \\
\text { DLT } \\
\text { MTD } \\
\text { Phase } 2\end{array}$ & $\mathrm{U}$ & 54 & $\ldots$ \\
\hline Chemohormonal ther & & & & & & 3-yr PFS & & & \\
\hline $\begin{array}{l}\text { NCTO2543255 } \\
\text { ACDC }\end{array}$ & 2 & $\mathrm{NA}$ & $C T 2 c-3, P S A=20 . b G S 8-10$ & - & $\begin{array}{l}\text { Arm 1: Abiraterone } 1 \mathrm{~g} / \mathrm{d}+\text { prednisone } \\
5 \mathrm{mg} \times 2 / \mathrm{d}+\text { leuprolide } 22.5 \mathrm{mg}+ \\
\text { cabazitaxel } 25 \mathrm{mg}^{2} \mathrm{~m}^{2} \\
\text { Arm 2: Abiraterone } 1 \mathrm{~g} / \mathrm{d}+\text { prednisone }\end{array}$ & рто & $\mathrm{R}$ & 76 & August 2020 \\
\hline NCT02849990 & 2 & $\mathrm{~N} / \mathrm{A}$ & $\begin{array}{l}\text { СТ3a or CT3b-4 and/or bGS } \geq 8 \text { and/or } \\
\text { PSA }>20 \mathrm{ng} / \mathrm{ml}\end{array}$ & - & $\begin{array}{l}5 \mathrm{mg} \times 2 / \mathrm{d}+\text { leuprolide } 22.5 \mathrm{mg} \\
3 \text { mo apalutamide (ARN } 509 \text { ) } 240 \mathrm{mg} / \\
\mathrm{d} \text { * abiraterone } 1000 \mathrm{mg} / \mathrm{d} \text { + } \\
\text { prednisone } 5 \mathrm{mg} \times 2 / \mathrm{d}+3 \text { doses of } \\
\text { degarelix }\end{array}$ & pro & Not $\mathrm{R}$ & 22 & July 2020 \\
\hline $\begin{array}{l}\text { NCTO0430183 } \\
\text { PUNCH } \\
\text { CAICB } 90203\end{array}$ & 3 & $\mathrm{NA}$ & $\begin{array}{l}\text { Probability of } 5 \text { yr BFS }>60 x \text { and } / o r \\
\text { bCS }>8\end{array}$ & - & $\begin{array}{l}\text { Arm } 1: 3 \text { weekly, } 6 \text { cycles docetaxel } \\
75 \mathrm{mg} / \mathrm{m}^{2}+18 \ldots 24 \text { wk L.HRita } \\
\text { Arm } 2: \text { None }\end{array}$ & 3-yr BRIS & $A$ not $R$ & 788 & October 2018 \\
\hline
\end{tabular}


Table 5 (Continued)

\begin{tabular}{|c|c|c|c|c|c|c|c|c|c|}
\hline Reference & Phase & TT & Risk factors & EBRT & Arms & I endpoint & Status & SS & $\begin{array}{l}\text { Estimated } \\
\text { completion date }\end{array}$ \\
\hline $\begin{array}{l}\text { Guerif et al. [80] } \\
\text { NCT01994239 } \\
\text { GETUG-AFU22 } \\
\text { Other }\end{array}$ & 2 & $A D$ & $\begin{array}{l}\text { PSM } 0-1, \text { pN0-x, detectable PSA postop } \\
\text { PSA } \geq 0.2 \text { but } \leq 2 \\
\text { pNO-x, MO }\end{array}$ & $\begin{array}{l}\text { EBRT } \\
\text { Pelvis } 46 \mathrm{~Gy} / 23 \mathrm{f} \\
\text { Prostate } 66 \mathrm{~Gy} / 33 \mathrm{f}\end{array}$ & $\begin{array}{l}\text { Arm 1:6-mo degarelix } \\
\text { Arm 2: None }\end{array}$ & $\begin{array}{l}\text { 5-yr event-free } \\
\text { survival }\end{array}$ & $\bar{R}$ & 120 & June 2025 \\
\hline NCT01804712 & 1 & NA & $\begin{array}{l}\text { Preoperative probability to be free of } \\
\text { disease at } 5 \text { yr }<60 \% \text { or } G S \geq 8\end{array}$ & - & 4 wk rituximab $375 \mathrm{mg} / \mathrm{m}^{2} / \mathrm{wk}$ & Histology response & A not $R$ & 18 & April 2019 \\
\hline NCT02111187 & 1 & NA & $\begin{array}{l}\mathrm{CT} 3-4 \text { and/or bGS } 8-10 \text { and/or iPSA } \\
>20\end{array}$ & - & $\begin{array}{l}\text { Arm 1: 4-wk LDE225 } 800 \mathrm{mg} \\
\text { Arm 2: None }\end{array}$ & Gli1 expression & $\mathbf{R}$ & 14 & March 2017 \\
\hline NCT01385059 & 2 & NA & $\begin{array}{l}\mathrm{cT} \geq 3 \mathrm{a} \text { and/or } \mathrm{iPSA}>20 \text { and } / \text { or } \operatorname{cGS} 8- \\
9\end{array}$ & - & $\begin{array}{l}\text { Arm 1: 28-d axitinib } \\
\text { Arm 2; None }\end{array}$ & No. of VEGFR1 & 0 & 60 & January 2019 \\
\hline NCT01194271 & 2 & NA & iPSA $\geq 20$ or $b G S \geq 8$ & - & $\begin{array}{l}\text { Leuprolide } 22.5 \mathrm{mg}+2 \text { doses of } \\
\text { ipilimumab } 10 \mathrm{mg} / \mathrm{kg}\end{array}$ & $\begin{array}{l}\text { Longitudinal } \\
\text { peripheral blood } \\
\text { values }\end{array}$ & $\mathrm{C}$ & 19 & - \\
\hline NCT01759836 & 2 & $\mathrm{AD}$ & $\begin{array}{l}\mathrm{pT} 3-4 \text { or PSM or } \\
\mathrm{pGS} \geq 8\end{array}$ & - & $\begin{array}{l}\text { Arm 1: 1-yr atorvastatin } 20 \mathrm{mg} / \mathrm{d} \\
\text { Arm 2: Placebo }\end{array}$ & $\mathrm{BR}$ & $\mathbf{U}$ & 354 & - \\
\hline
\end{tabular}




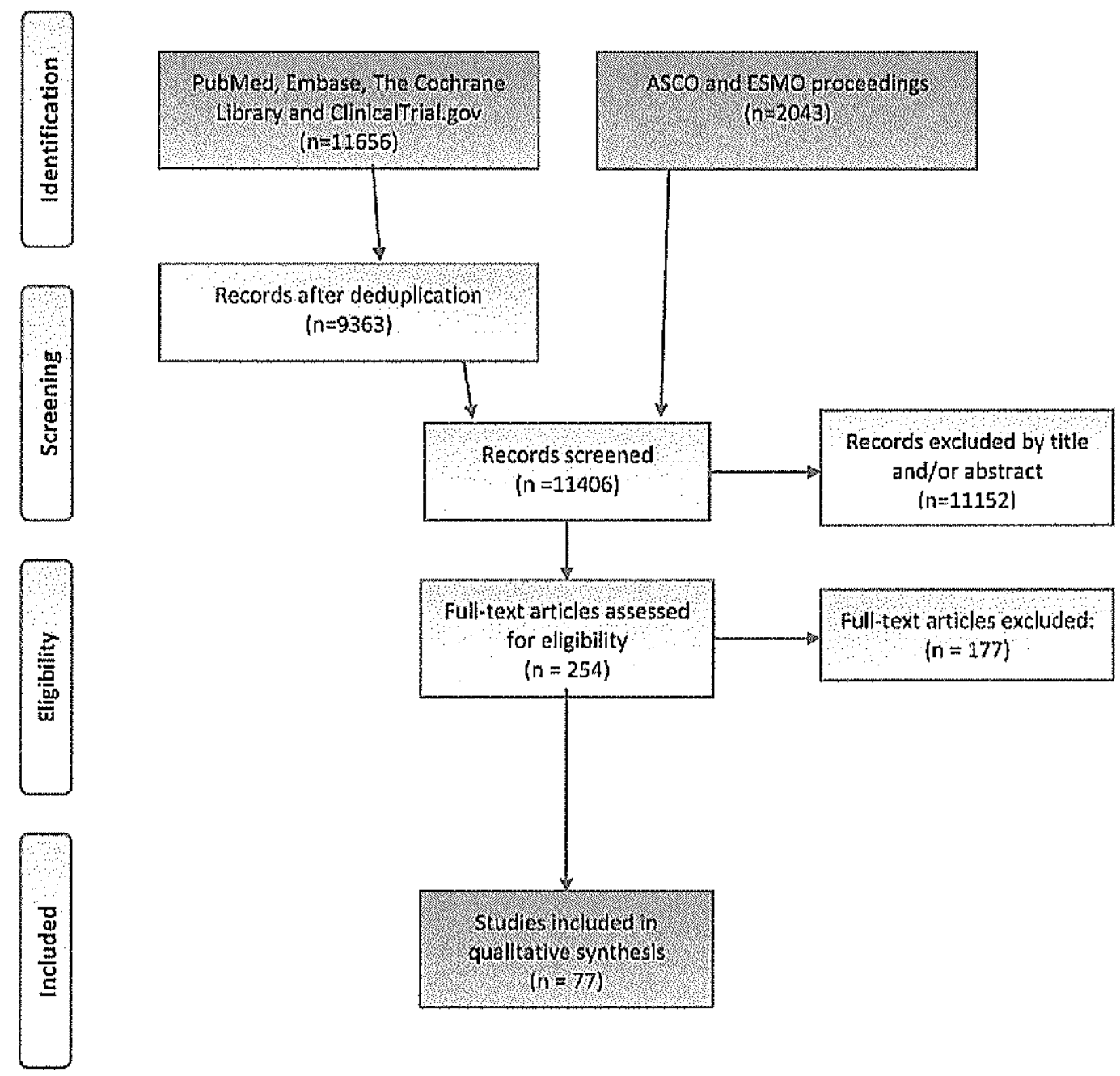

Fig. 1 - PRISMA flow diagram. ASCO = American Society of Clinical Oncology; ESMO = European Society of Medical Oncology; PRISMA = Preferred Reporting Items for Systematic Reviews and Meta-analysis. 